\title{
Post-glacial persistence of turbiditic activity within the Rhône deep-sea turbidite system (Gulf of Lions, Western Mediterranean): Linking the outer shelf and the basin sedimentary records
}

\author{
Bernard Dennielou ${ }^{\mathrm{a},{ }^{*}}$, Laurent Jallet ${ }^{\mathrm{b}}$, Nabil Sultan ${ }^{\mathrm{a}}$, Gwenael Jouet $^{\mathrm{a}, \mathrm{c}}{ }$, Pierre Giresse $^{\mathrm{b}}$, \\ Michel Voisset ${ }^{a}$ and Serge Berné ${ }^{a, b}$
}

\footnotetext{
a IFREMER, Département des Géosciences Marines, BP70, 29280 Plouzané, France

b IMAGES, Université de Perpignan, Bâtiment U, 52 Avenue Paul Alduy, 66000 Perpignan, France

c IUEM, UMR 6538 Domaines Océaniques, Université de Bretagne Occidentale, Place Nicolas Copernic, 29280 Plouzané, France
}

*: Corresponding author : Dennielou B., Tel.: +33 2982242 22; fax: +33 2982245 70, email address : Bernard.Dennielou@ifremer.fr

\begin{abstract}
:
Emplacement of post-glacial turbidites is commonly controlled by rapid changes in sea level or by seismicity. On the continental rise of the Gulf of Lions (Western Mediterranean), an aseismic area, we identified turbiditic beds deposited during the rising stage and highstand of sea level. Swath bathymetry, sediment cores, in situ Cone Penetrating Tests (CPTU), heavy mineral associations and radiocarbon dating determined the source, composition, distribution and age of the turbiditic beds. Turbidites are composed of homogeneous to positively graded silts to medium sand with quartz (up to $90 \%$ ), shell debris and shelfal benthic faunas. Their distribution on the sea floor is very patchy and controlled by abundant inherited erosional bedforms. Their source is found in relict regressive sands at the outershelf. Their deposition occurred just after the onset of the post-glacial sea level rise and the concomitant sediment starvation of the Rhône deep sea turbiditic system until recently. Whilst canyons are fed with sand by strong seasonal hydro-sedimentary dynamics on the outershelf, the emplacement of post-glacial turbidites is not controlled by sea level changes but probably by the periodic flushing of the canyons. Our study revealed that this low energy aseismic margin undergoes significant transport of sand, down to the base of slope, during the sea-level rise and the Holocene highstand.
\end{abstract}

Keywords: canyons; outer shelf; sand; turbidites; sea-level; Late Pleistocene; Holocene 


\section{Introduction}

Sand exportation from the continents down to deep sea areas mainly occurs via canyons and turbiditic channels. This dominantly occurs during sea level lowstand stages, when river mouthes used to be connected to canyon heads.

Other contexts and periods [cf. review of mass-transport deposits from Maslin et al. (2004)] have been reported, notably in open environments, such as in abyssal plains, during times of sea-level change, e.g. the Madeira, Agadir and Seine abyssal plains (Weaver and Rothwell, 1987; Wynn et al., 2002b), and during the Holocene, e.g in the Balearic Abyssal Plain (Rothwell et al., 2006), in the Horseshoe Abyssal Plain (Lebreiro et al., 1997) and the Balearic Abyssal Plain (Zuniga et al., 2007). This also occurs along continental slopes such as the Cascadia margin (Goldfinger et al., 2003) or the Markan continental slope (Prins et al., $2000 \mathrm{~b}$ ). In this context sand is transported by unconfined turbiditic flows that may initiate from the slope and which are possibly triggered by earthquakes (Goldfinger et al., 2003; Hieke and Werner, 2000; Lebreiro et al., 1997; Rothwell et al., 1998), and use adjacent canyons as a pathway. Examples of deep-sea high-stand coarse turbiditic deposits, despite no direct canyon-river connection, have been described in the Cap Timiris canyon (Wien et al., 2006), in the Indus canyon (Prins et al., 2000a), in the Bengal « Swatch of No Ground » canyon (Weber et al., 1997), on the Amazon fan (Flood and Piper, 1997), on the Celtic fan (Zaragosi et al., 2000), on the Armorican turbiditic system (Zaragosi et al., 2001), on the Hueneme and Dume fans (Normark et al., 1998). These deposits are interpreted as the product of reworked outer shelf or canyon head sands (Flood and Piper, 1997; Zaragosi et al., 2000; Zaragosi et al., 2001), or of across-shelf sediment transport (Weber et al., 2003). They contrast with the classical concept of eustatic control of submarine fan development (Shanmugam et al., 1985), where the present flooding of the shelf would prevent the transfer of coarse sediment into the deep basin.

On the continental rise of the Gulf of Lions (western Mediterranean), at the foot of the canyon drainage network, in the vicinity of the Petit-Rhône deep-sea turbiditic system, (Fig. 1), several sediment cores sampled up to 30 silty and/or sandy layers, intercalated in hemipelagic deposits from the last glacial termination and from the Holocene. These layers were deposited during and after the last major sea-level rise. They overlay turbiditic spillover deposits in the distal part of the turbiditic channel of the Rhône deep-sea turbiditic system (Bonnel et al., 2005).

This paper deals with sedimentological evidences of post-glacial coarse sediment deposition and erosion at the base of slope in the Gulf of Lions during the last interglacial stage. We will focus on the distribution, composition, chronology and possible sources of these silt-sand layers. We will discuss the control of sea-level climate, physiography, and hydrography on the deposition of these layers.

\section{Morpho-sedimentary setting}

In the Gulf of Lions (western Mediterranean) the build up of the margin was strongly controlled by Quaternary glacial-interglacial sea-level variations and by significant subsidence at the shelf edge that led to the deposition and preservation of various types of sedimentary bodies and to numerous canyons dissecting the continental slope (Baztan et al., 2005; Berné et al., 2001) (Fig. 1).

The Rhone River is the main provider of sediments for the area and depot centres have moved across the margin concurrent to sea level changes. During the last sea-level rise and high stand sediments were stored in submarine prodeltas, still visible on the present seabed morphology, (Berné et al., 2007; Labaune et al., 2005) and partly redistributed to the west along the inner shelf through anti-clockwise circulation induced by general circulation and wind (Millot, 1991). During the last sea-level regression and low stand, sediments 
accumulated on the outer shelf, on the upper slope and the deep sea areas. On the outer shelf, between $-110 \mathrm{~m}$ and $-90 \mathrm{~m}$, are deposits of littoral prograding shoreface sands (Aloïsi, 1986; Berné et al., 1998; Berné et al., 1999; Bourcart, 1945; Jouet et al., 2006; Monaco, 1971) of median grain size ranging from $200 \mu \mathrm{m}$ to $500 \mu \mathrm{m}$ ) and composed of $25-50 \%$ of bioclastic carbonates. On the upper slope are deposits of fine-grained prodeltaic mud presently preserved on canyon interfluves (Rabineau et al., 1998; Tesson et al., 1990). During the low stand period, the base of slope collected most of the fluvial sediment which accumulated at the Pyreneo-Languedocian Ridge and the Rhone turbidite system (Fig. 1) (Bonnel et al., 2005; dos Reis et al., 2004; Droz and Bellaiche, 1985; Droz et al., 2006; Jallet and Giresse, 2005 ; Méar, 1984). The Pyreneo-Languedocian Ridge and the Petit-Rhône deep-sea turbiditic system have been growing concomitantly since the Middle Pleistocene (dos Reis et al., 2004; Droz and Bellaiche, 1985; Droz et al., 2006). On the western flank of the Rhône turbiditic system lies a Mass Transport Deposit, of probably the last glacial maximum, (Droz and Bellaiche, 1985; Gaullier et al., 1998; Méar and Gensous, 1993). Above, lie deposits from the last avulsion of the Rhone turbiditic channel called "neofan" (Bonnel et al., 2005; Droz and Bellaiche, 1985; Torres et al., 1997). Since 18.4 cal. ka BP spillovers of river-fed turbiditic flow from the neochannel have stopped (Beaudouin et al., 2004; Bonnel et al., 2005; Dennielou et al., 2006). 12 kHz (EM12) and 30 kHz (EM300) multibeam backscatter data, from previous studies (Bonnel et al., 2005; Droz, 1983) revealed two lobe-shaped adjacent areas at the outlet of the Sète canyon network and at the outlet of the La Fonera Canyon (LFC), with respectively heterogeneous low backscatter and lineated moderate backscatter (Bonnel et al., 2005; Droz et al., 2001) (Fig. 2). These lobe shape areas have been interpreted as zones of heterogeneous superficial material (Bonnel et al., 2005; Droz et al., 2001), probably less than $1 \mathrm{~m}$ deep.

Wave-cut terraces (Jouet et al., 2006) and wavy bedforms (Berné et al., 1998) reshaped the outer shelf sands and are inherited from the marine transgression that followed the Last Glacial Maximum low stand. Recent investigations have demonstrated that present hydrodynamic processes maintain a mobile reworked carpet, up to few meters thick, on top of these deposits (Bassetti et al., 2006). Transfer into the canyon heads, related to episodic dense water cascading, is currently observed (Gaudin et al., 2006; Palanques et al., 2006). Several canyons, Marti canyon (MC), Herault canyon 2 (HC2), HC3, Bourcart canyon 2 (BC2), Lacaze-Duthier Canyon (LDC) and Cap de Creus Canyon (CCC) (Baztan et al., 2005) and Petit-Rhône canyon (PRC) (Torres et al., 1997) display a marked axial incision that is interpreted as the imprint of erosive turbidity current initiated at the canyon head when it was connected to a river during the last sea-level low stand (Baztan et al., 2005).

At the base of slope scour holes of varied size and morphology (up to $5 \mathrm{~km}$ long and $2 \mathrm{~km}$ wide) (Bonnel et al., 2005; Kenyon et al., 1995; Lastras et al., 2007a) are erosive features indicative of hydraulic jumps undergone by turbiditic currents. Giant amalgamated scours (Fig. 3) and distal spoon-shaped scours are attributed to hydraulic jumps at the Rhone neochannel-lobe transition zone, (Bonnel et al., 2005; Kenyon et al., 1995; Wynn et al., 2002a). Irregular to crescentic scours at the most distal reaches of the Sète Canyon (SC) are attributed to similar bed load transport and erosion from the Sète canyon network (Lastras et al., 2007a)

\section{Heavy mineral sources}

In the Gulf of Lions, heavy minerals are supplied dominantly by the Rhone River but also by smaller rivers such as (from east to west) Hérault, Orb, Aude, Agly, Têt and Tech, and by coastal erosion. Among the studies on heavy mineral associations (Duplaix, 1972; Duplaix and Lalou, 1951; Monaco, 1971; Van Andel, 1955; Vatan, 1949) the synthesis by Duplaix (1972) on shorelines determined 3 provinces characterised by specific mineralogical associations: (1) Pyrenees (common hornblende + andalusite), (2) Languedoc (staurolite + augite) and (3) Alps (bluish-green hornblende + augite + epidote + garnet). Samples 
collected at Lacaze-Duthier and Pruvost canyon heads (85 m-100 m water depth) display a Pyrenees association and do not significantly differ from samples taken from the Roussillon littoral, suggesting a similar source (Duplaix, 1972), although the increase in grain size leads to an increase in the abundance of andalusite. Samples collected in the BC head display a mixed Pyrenees-Alps association (Duplaix, 1972).

\section{Material and methods}

A swath bathymetry dataset acquired with a EM300 generated a digital terrain model with a grid interval of $50 \mathrm{~m}$ and a vertical resolution of about $2 \mathrm{~m}$. MAK1-M 30kHz side-scan sonar (SSS) data from Kenyon et al. (1995) provide a resolution of between 1 and $7 \mathrm{~m}$ (Lastras et al., 2007a). For acoustic backscatter data (SSS and EM300), dark tones represent high backscatter and light tones represent low backscatter.

Eighteen sediment cores were collected at the base of slope from the Rhone neochannellobe transition zone within and outside the scours from the neochannel-levee, from the Rhone abandoned channel-levee and from a turbiditic levee upstream the neochannel bifurcation (Fig. 2) at a water depth ranging from between 2025 and 2506 metres (cf. Fig. 2, 3,4 for details on their location). Sediment cores were retrieved with a Calypso (piston) corer (labelled MD), a Kullenberg (piston) corer (labelled KS) and a push corer (labelled KI).

X-ray photographs were taken with the SCOPIX system (Migeon et al., 1999) and processed according parts of the procedure by Lofi et al. (2001).

Grain size analyses were performed on a Coulter LS200 laser microgranulometer with no chemical pre-treatment of the samples. The grain-size classification for clay $(<3.9 \mu \mathrm{m})$, coarse silt $(>3.9 \mu \mathrm{m}$ and $<63 \mu \mathrm{m})$, very fine sand $(>63 \mu \mathrm{m}$ and $<125 \mu \mathrm{m}$, fine sand $(>125 \mu \mathrm{m}$ and $<250 \mu \mathrm{m})$, and medium sand $(>250 \mu \mathrm{m}$ and $<500 \mu \mathrm{m})$ correspond to the UddenWentworth grain-size classification (Wentworth, 1922).

For heavy mineral investigation, the bulk sediment was sieved into two grain-size classes, 50-160 $\mu \mathrm{m}$ and $160-500 \mu \mathrm{m}$. Heavy minerals were extracted from these classes by density fractionation in bromoform $\left(\mathrm{CHBr}_{3}\right)$ of density $2.89 \mathrm{~g} . \mathrm{cm}^{-3}$. After rinsing with alcohol, heavy minerals were glued on a slide with a resin. The identification of minerals is based on the shape, colour, cleavages, relief (natural light), extinction angle and birefringence colour (cross nicols)and optic sign (converging light). When possible, a minimum of 100 minerals was counted to ensure statistical reliability. For 6 beds less than 100 minerals were counted. Counting of heavy minerals was processed by Principal Component Analysis (PCA) in order to calculate the correlations between the minerals and then to determine the principal components that can be interpreted as possible end members or sources. Classification of the samples was made by Hierarchical Ascending Classification (HAC), based on PCA scores of samples for the three most important principal components.

AMS radiocarbon dating was conducted on mono and bi-specific planctonic foraminifera for most of the samples and on mixed foraminifera for some samples, depending on the amount of material available (Tab. 1). The age of the silt-sand layers was determined by dating the hemipelagic sediment above the layers. Dating of sediment below the beds was avoided when possible because of possible erosion of the substratum at the deposition of the beds. Calibration into calendar scales was calculated by Calib 5.0.2 software (Stuiver and Reimer, 1993) with the marine calibration curve (Hughen et al., 2004). No deviation from the mean global reservoir correction (-408 yr) have been applied. Calendar ages are given with 1 sigma standard error. Ages of silt-sand layers, based on one analysis, are given in conventional radiocarbon ages. Ages of beds, based on averages of several analyses, are given in calendar ages. Time intervals are given in calendar scale. Radiocarbon dating and calibrations are listed in Table 1.

In situ measurements were carried out with the "Module Géotechnique" penetrometer (Baltzer et al., 1994) along two transects (MGGC-03 and MGGC-04). Measurements within each area were performed at several locations labelled with a suffix (e.g. MGGC-03-S1, 
MGGC-03-S2, etc). The "Module Géotechnique" is equipped with an electric cone at the end of a rod that is pushed into the sediment at a constant rate in order to conduct a CPTU (Cone Penetration Test with additional measurement of the pore water pressure). The electric cone used during the GMO2-CARNAC cruise gave a continuous measurement of the tip resistance $(q c)$ and excess pore pressure $\left(\Delta u_{2}\right)$ measured by means of a porous filter located immediately behind the cone (called $U 2$ type cone). The maximum penetration of the CPTU is $2 \mathrm{~m}$ below the seafloor (mbsf). An important application of CPTU measurements is the prediction of the stratigraphy and lithology of buried sediments. One CPTU parameter alone is difficult to interpret in terms of lithology. In view of the lack of the sleeve friction measurements, in this study we used the soil classification chart proposed by Ramsey (2002) and based on $q c$ and $\Delta u_{2}$. In addition to this classification, we also interpreted intervals with concomitant increasing tip resistance and decreasing pore pressure as indicative of porous material and, therefore, possible coarse layers.

The amount and characteristics of silt-sand layers vary from one core to another. According to our knowledge of sedimentary bodies in the study area, and to the chronostratigraphic control, we can confidently affirm that the time interval spanning from the glacial termination to the Holocene has been recovered in all cores. Therefore, the discrepancy in the amount of silt-sand layers from one core to another corresponds to a real sedimentological variability, and not to a discrepancy in the time interval sampled. On the other hand, as the spatial distribution of sediment cores is not homogeneous, it is possible that other existing silt-sand beds were not sampled. The chronological framework is based on radiocarbon dating. When no radiocarbon dating was available, correlations between cores is based on interpolation and lithological correlations.

Herein, they will be called "silt-sand layers" when described in sediment cores and "silt-sand beds" when referring to the spatial distribution of the layers.

\section{Results}

\subsection{Sediment classification, facies and sequences}

Sediment classification is after ODP Leg 155 Shipboard-Scientific-Party (1995) and is based on the relative proportions of biogenic and lithic fractions (Tab. 2). Textural classification is that of (Shepard, 1954). Facies 1 and 2, consist of foraminifera and calcareous nannoplankton silty-clay. Color is light beige and bioturbation is abundant. Basal and top contact is gradational or sharp. A noticeable change in the lightness corresponds roughly to the transition between less (facies 2, darker) and more than $40 \%$ of carbonates (facies 1 , ligther) (Dennielou et al., 2006) (Fig. 4). Facies 3 consists of a pteropod ooze containing more than $90 \%$ of coarse sand size pteropod shells. Colour is beige. Basal and top contact is sharp. Facies 4 consists of coarse silts to fine sand dominantly made of quartz with occasional shelfal benthic foraminifera and shell debris. Colour is grey or beige. Internal structures such as horizontal laminations or climbing ripples are common. Basal contact is sharp or erosional. It occurs as millimetre to centimetre thick layers. Facies $\mathbf{5}$ consists of silty-clay with abundant silt laminae and centimetre thick silt layers. Colour is grey and bioturbation is absent. Silts are dominantly composed of quartz. Facies 6 is composed of stiff silty-clay. Colour is grey and bioturbation is absent. Abundant colour banding and silt laminae are horizontal or oblique and show frequent distorsion. Top contact is sharp and basal contact was never recovered in the core.

Sedimentary sequences can be defined on the basis of sedimentary processes interpreted from the sedimentary facies:

Pelagic sequences: represented by facies 3. Observed in two cores only, KIGC-04 and KSGC-14 up to $10 \mathrm{~cm}$ thick layers. Similar intervals were described in the Rhone turbiditic channel (Bellaiche and Thiriot-Quievreux, 1982). 
Hemipelagic sequences: represented by facies 1 and 2. It drapes the turbiditic deposits and the mass-transport deposits.

Turbiditic sequences: represented by facies 4 and facies 5 . Facies 5 corresponds to silt mud turbidites corresponding to Te terms of base cut out Bouma sequences and T3 terms of Stow and Piper (1984) classification. It is attributed to deposits from spillover from the Rhone turbiditic channel. Near the neochannel it is attributed to the Neofan Transparent Unit of Bonnel et al. (2005). More details on this facies is found in Dennielou et al. (2006). Facies 4 corresponds to silt-sand turbidites corresponding to Td term base cut out and top cut out Bouma sequences. It is always interbedded in the hemipelagic sequence.

Mass-transport sequences: represented by facies 6. It is interpreted as the Western Mass Transport Deposit (WMTD) described in Droz and Bellaiche (1985) and Bonnel et al. (2005), also called Intermediate Unit in Gaullier et al. (1998) and Unit B in Méar and Gensous (1993) In situ geotechnical data show that cohesion of sediment increases with depth (Fig. 8). Tip resistance and differential pore pressure are positively correlated in low porosity material such as in pelagic, hemipelagic and sequences. In porous material, such as coarser material from facies 4 and facies 5 in turbiditic sequences, the tip resistance increases rapidly and is accompanied by a rapid drop in differential pore pressure. Numerous low amplitude changes of both tip resistance and differential pore pressure superposed on an increasing trend (Fig. 8 , dotted pattern) are interpreted as laminated tubidites (facies 5 ). We found no evidence that mass transport sequences were reached by in situ cone penetrating tests.

\subsection{Sedimentological characteristics of silt-sand layers (facies 4)}

A total of 30 silt-sand layers corresponding to Facies 4 was investigated for composition, grain-size and sedimentary structures. Composition of facies 4 is dominantly silico-clastic with a minor but significant amount of biogenic components. Quartz, representing always more than $75 \%$ of the composition and usually more than $90 \%$, is dominantly round shaped and displays a wide range of colours (transparent, opaque and stained). The surface of quartz grains is dominantly smooth. Detrital carbonates and micas are common. A clay layer is present on top of the silt-sand layer in three beds only, MD99-2345 $100-121 \mathrm{~cm}(80 \%$ of thickness), MD99-2345 146-198 cm (50\%) and KIGC-07 40-45 cm (75\%, bioturbated). The biogenic fraction consists of shell debris, planktonic and benthic foraminifera among which Ammonia and Elphidium are genus indicative of shallow water and nearshore environment (Gaudin et al., 2006). The composition of the silt-sand layers is controlled by grain size. Biogenic components are more abundant in coarser layers, quartz is dominantly smoothed in coarser layers while it is dominantly angular in finer layers (e.g. KIGC-03 $24-30 \mathrm{~cm}$, Fig. 5).

The median grain size ranges from about $30 \mu \mathrm{m}$ to $972 \mu \mathrm{m}$ but is dominantly at $200 \mu \mathrm{m}$ (Fig. 6). Fifteen layers show normal grading, 11 layers show constant grain size, 2 layers shows reverse grading, 2 layers show no grading followed by normal grading (e.g. KIGC-06 24-32 $\mathrm{cm}$ and KIGC-07 6-16 cm, Fig. 5). The grading is usually constant but can be stepped as in the thickest beds. The grain size distribution is commonly very well-sorted.

Layer thickness ranges from one millimetre to $34 \mathrm{~cm}$ but $80 \%$ of the bed thicknesses range from one millimetre to $7 \mathrm{~cm}$. Displays of sediment disturbance (upward bending of layers) on piston cores suggest over-sampling of the silt-sand layers and exaggerated thicknesses in cores MD99-2344, MD99-2345 and MD01-2437. This is a disturbance commonly observed on piston cores (Auffret et al., 2002; Skinner and McCave, 2003). It was also confirmed by a short push core, duplicate of core MD99-2345, showing that exaggeration in the piston cores is two-fold.

Several combinations between basal contact, grading and sedimentary structures determine three sub-facies for Facies 4: Facies 4a consists of well-sorted, massive or poorly graded coarse silt or fine sand and dominantly sharp base. Facies $\mathbf{4 b}$ consists of well-sorted, laminated, normally graded, coarse silt or fine sand and dominantly erosional base. Facies 4c consists of coarse silt and fine sand with climbing ripples and erosional base. 


\subsection{Temporal distribution of silt-sand layers}

Among the 30 layers identified, the visual description and radiocarbon dating results in distinguishing 12 periods of deposition whose ages are listed in Tab. 3 . The time window for a period of deposition varies from $92 \mathrm{yr}$ to $819 \mathrm{yr}$ and depends on the amount of layers sampled and on intrinsic uncertainty related to the dating method. Therefore, one period could correspond to several beds, very close in time, with a very limited geographical extension, lower than our coring grid. This may be the case of bed \#1 that comprises one layer dated at $840 \pm 30{ }^{14} \mathrm{C}$ yr BP in core KSGC-10 and several other layers dated (or correlated) at $1670 \pm 30{ }^{14} \mathrm{C}$ yr BP in 4 other cores.

The deposition of the beds spans the whole period from the post-glacial to the end of the Holocene, from $18400 \mathrm{cal}$. yr BP to $450 \mathrm{cal}$. yr BP. The first bed (\#12) was deposited just after the end of the turbiditic spillover from the neochannel and is concomitant to the onset of the sea-level rise (Camoin et al., 2004). It is followed by the deposition of beds \#11 to \#8 within a time interval of $2800 \mathrm{cal}$. yr. Bed \#7 and bed \#6 were respectively deposited before (12 700 cal. yr BP) and after (10 200 cal. yr BP) the Younger Dryas. Beds \#5 to \#1 were deposited almost at regular intervals during the Holocene from $7700 \mathrm{cal}$. yr BP to $900 \mathrm{cal}$. $\mathrm{yr}$ $\mathrm{BP}$. The young age of bed \#1 suggests that the source and trigger mechanism for these siltsand beds could still be operative.

\subsection{Spatial distribution of silt-sand beds}

Because of their slight thickness, the silt-sand beds cannot be resolved by acoustic methods such as chirp or conventional sediment penetrator $(3.5 \mathrm{kHz})$. Therefore, their spatial distribution could only be assessed with sediment cores and in situ geotechnical measurements.

Geotechnical data (Fig. 3) identify the main lithologies of the area and, especially, those from the western discordant body and from the hemipelagic drape, including potential silt-sand layers (Fig. 8). The amount of potential silt-sand layers revealed by geotechnical data is similar to the amount described in sediment cores (Figs. 9 and 10). Silt-sand layers, together with the hemipelagic drape, are not abundant at the bottom of the deepest scours and on the steepest slopes as also shown on sediment penetrator profiles and on sediment cores (KIGC-02, and KSGC-10) from a giant scour (Fig. 11).

No sediment core sampled the whole set of silt-sand beds, showing that their spatial distribution is very limited and/or patchy. However, half of the 12 beds (\#1, 3, 4, 6, 7 and 10) were sampled by at least 2 cores while others $(\# 2,5,8,9,11,12)$ were sampled once only. The distribution of the beds is shown on detailed maps in Fig. 7. Bed \#1 has been sampled 6 times according to radiocarbon dating and to stratigraphical correlations (Fig. 4). It is restricted to a narrow strip no more than $10 \mathrm{~km}$ long and $40 \mathrm{~km}$ wide with a NW-SE direction. Within this strip, this bed is absent from 3 cores. Bed \#4 was sampled up to 6 times and shows the same distribution as bed \#5, apart from one location close to the neofan channel (core MD99-2344). Bed \#3 was sampled in the same strip as bed \#1 and bed\#4 (core KIGC07) and $30 \mathrm{~km}$ further to the southwest (core MD99-2345), but not in other cores from the strip. Bed \#6 was sampled in the eastern part of the area in two cores distant by $20 \mathrm{~km}$. Bed \#7 is also located on the eastern part and is found in the northernmost core (KGMO-10) and possibly on the distal part of the neofan (core MD01-2437). Bed \#10 is also located in the eastern part, in cores close to the Petit-Rhône turbiditic channel (KGMO-10), neochannel (MD99-2344) and abandoned channel (KSGC-14), suggesting a source from the PRC. Beds \#2 and \#5 are found south of the area (core MD99-2345) and beds \#8, \#9, \#11 and \#12 are found north of the study area (core MD99-2344).

The very variable bed thickness observed, for instance for bed \#1 and bed \#4 (Fig. 5), and the very erosional base of bed \#4 (Fig. 5), is a display of strong current interaction with seabed morphology and further supports a spatial patchy distribution, even probably to the scale of less than 1 metre. 


\subsection{Volume of silt-sand beds}

All beds are located within the Sète lobe and the La Fonera lobe described by Droz et al. (2001), thus one may postulate that they correspond to their spatial distribution (Fig. 2), therefore, allowing to estimate the volume of silt-sand deposited in this area since the onset of sea-level rise. The surface of the Sète lobe can be estimated at $1301 \mathrm{~km}^{2}$ but, according to its patchiness, the area of deposition of the sandy beds can be estimated at half of its surface, i.e. $651 \mathrm{~km}^{2}$. The surface of the La Fonera lobe can be estimated at $811 \mathrm{~km}^{2}$. The average thickness for the whole set of beds is about $10 \mathrm{~cm}$ per core. Therefore, the whole volume of sand deposited can be estimated at about $0.15 \mathrm{~km}^{3}$.

\subsection{Age of the hemipelagic drape}

Of the 18 sediment cores studied, only three (MAKS00-18, KIGC-02 and MD01-2435) do not display a coarse layer in the hemipelagic drape lying over the NTU or the WMTD. Erosional features such as several sizes of scours are visible all over the area (Bonnel et al., 2005; Kenyon et al., 1995; Wynn et al., 2002a). At the same locations, there is also variability in the age of the base of the hemipelagic drape over the area, even when several coarse layers are present (Figs. 3 and 4). The ages range from $840 \pm 30{ }^{14} \mathrm{C} \mathrm{yr}$, in the giant scour, to $15510 \pm 50{ }^{14} \mathrm{C}$ yr on the right levee of the neofan. A set of ages around $15000{ }^{14} \mathrm{C} \mathrm{yr}$ is found on the north-eastern part of the study area, corresponding to the shallowest part of the area and to the area closest to the Petit-Rhône turbiditic channel and neochannel. On the contrary, younger ages ranging from $10100 \pm 50^{14} \mathrm{C}$ yr to $840 \pm 30{ }^{14} \mathrm{C}$ are found in the depression, where erosional bedforms are pervasive. Younger ages are also found in other sites also with no silt-sand layer, the neochannel (core MAKSO0-18 at $10100 \pm 50^{14} \mathrm{C} \mathrm{yr}$ ) and the turbiditic right levee, upstream the neochannel avulsion (core MD01-2435 at 12 $100 \pm 50^{14} \mathrm{C}$ yr).

The variability in the age of the base of the hemipelagic drape and the lack of older silt-sand layers highlights hiatuses of sedimentation, corresponding to periods of erosion, as demonstrated by the sharp or erosional contact between the hemipelagic drape and the turbidite facies. Contrarily, for ages around $15000{ }^{14} \mathrm{C} \mathrm{yr}$, the transition from the turbidite facies to the hemipelagic drape is gradual.

\subsection{Heavy mineral assemblages within coarse beds}

\subsubsection{Principal Component Analysis (PCA)}

PCA has allowed for statistical determination of the correlation of heavy minerals, in order todetermine end members that can be interpreted in terms of sources of the heavy mineral. Three principal components explaining $47.3 \%$ of the total variance can be distinguished $(17.7 \%, 16.3 \%$ and $13.4 \%)$. These percentages are low because a high proportion of the variance is also probably explained by the grain-size of the samples. When using a grainsize parameter for PCA, no satisfactory results were found. No variable (i.e. mineral) with correlation coefficient $\left(r^{2}\right)>0.6$ was found. In order to determine the significant minerals for the three components an exponential curve was fit to the growing distribution of the correlation coefficient. Only minerals with a correlation coefficient higher than the maximum curvature of the curve fit were considered as significant (Fig. 12). Once reported on correlation circles it is possible to determine the following end members on three axes: axis 1 , hornblende-glaucophane and andalusite-augite-zircon; axis 2, aegirine-augitehypersthene-kyanite and garnet-zircon; axis 3, aegirine-epidote and staurolite-kyanite (Fig. 12). Each axis is characterized by a dominantly "Alps" end member according to the classification by Duplaix (1972). Hornblende-glaucophane for axis 1, aegirine-augite- 
hypersthene-kyanite for axis 2 and aegirine-epidote for axis 3. The other end members are closer to the Pyrenee-Languedoc association (andalusite-augite-zircon on axis 1 and garnetzircon on axis 2) or the Languedoc association (staurolite-kyanite on axis 3).

5.7.2. Ascending Hierarchical Classification (AHC) and contribution of different sources in the silt-sand beds

In order to determine the importance of these end members in each sample, we conducted an ascending hierarchical classification $(\mathrm{AHC})$. The classification is based on the score obtained for each sample on the three axes from PCA. Twenty-seven samples were automatically sorted into 6 classes, and for each class the contribution of the principal axes allows interpretation in terms of mineral assemblage and sources (Fig. 13) according to the classification from Duplaix (1972):

Class $A$ is dominated by aegerine and epidote and also includes a homogeneous mix of andalusite, augite, aegirine-augite and hypersthene. The Alps (Rhone River) source is dominant, with a contribution from the Languedoc and Pyrenees sources.

Class $B$ is dominated by hornblende and glaucophane and then aegirine and epidote. The Alps source is exclusive.

Class $\mathrm{C}$ is dominated by staurolite and kyanite and then garnet and zircon. The Languedoc source is dominant with a minor contribution of the Pyrenees source.

Class $D$ is dominated by aegirine-augite and hypersthene and then hornblende and glaucophane. The Alps source is exclusive.

Class $E$ is dominated by staurolite and kyanite and then aegirine-augite and hypersthene. The Languedoc source is dominant with a significant contribution from the Alps source.

Class $\mathrm{F}$ is dominated by andalusite and augite and then garnet and zircon. The Languedoc and Pyrenees sources are exclusive.

Most of the beds show a mixture of several sources (Tab. 3). The dominant sources are the Alps and Languedoc sources and the contribution of the Pyrenees is minor. Reworking of the seabed by turbiditic currents is evidenced by the frequent erosional contacts at the base of silt-sand layers and may distort the source imprint on heavy mineral associations. However, a clear pattern for the sources can be drawn suggesting that mixing is not significant. Beds $\# 8$ and \#9 reveal an exclusive Alps source and bed \#12 an exclusive Languedoc source. A significant contribution of the Pyrenees source is observed for beds \#2, \#3, \#5 and \#7. Noteworthy, every bed from core MD99-2345 shows a contribution from the Pyrenees source with an emphasis for beds \#2 and \#3 (Fig. 13), and this is consistent with the southern position of the core, the closest to the Pyrenean LFC. For a few samples the determination of the source must be nuanced. Sample MAKS00-18 120-121 cm comes from coarse silt spillover deposits of the NTU and the core is located on the channel-side of the left turbiditic levee (Fig. 3). The source of sediment is believed to be the Rhone River (Beaudouin et al., 2004; Bonnel et al., 2005; Dennielou et al., 2006) but heavy minerals indicate an exclusive Languedoc-Pyrenees source mainly carried by the abundance of epidote and andalusite. Although important mixing from Languedocian and Pyrenean rivers cannot be discarded, the sieving at $50 \mu \mathrm{m}$ has preferentially extracted a minor coarse fraction from this dominantly silty sample, and may have over-sampled andalusite (Languedoc-Pyrenees source), that has a positive correlation with the grain-size and that is documented as rare or absent from the fine fractions (Duplaix, 1972), and under-sampled the aegirine-augite (Alps source), that has a negative correlation with the samples grain-size. The other sample from the NTU (MD992344-1052-1053) and the sample from the NCU (MD99-2437 810-811) show dominant Alps contribution consistent with sediment input from the Rhone River. 


\section{Discussion}

\subsection{Source of turbidite beds}

Coarse-grained and silt-sand deposits have already been reported in the study area (Beaudouin et al., 2004; Bonnel et al., 2005; Dennielou et al., 2006; Méar and Gensous, 1993) and interpreted as originating from the PRC and its prolongation as a turbiditic channel. Dispersal of spillover flows from the turbiditic neochannel is believed to be the main pathway until it ended around $15000{ }^{14} \mathrm{C}$ yr BP (low stand and initial stages of post-glacial) (Bonnel et al., 2005; Dennielou et al., 2006). The deposition of post-glacial and Holocene siltsand layers reported here came after the end of the river fed spillover of turbidititic flow from the turbiditic channel and shows characteristics that suggest other sources and processes. Although turbiditic sedimentary processes strongly control the grain size of the deposited material, these beds are much coarser (median dominantly at $200 \mu \mathrm{m}$ ) than the leveed turbidites from the neofan (median dominantly at $40 \mu \mathrm{m}$ ) (Dennielou et al., 2006) suggesting another source than the Rhone River. The biogenic composition reveals shallow water species also suggesting that the material has remained on the shelf and incorporated significant biogeneous shallow material. The "offshore sands" at the outer shelf (Aloïsi, 1986; Bassetti et al., 2006; Berné et al., 2001) represent good candidates for such a source. Except for the SC head, all canyon heads intersect these deposits (Fig. 1), making occasional transfer into the canyon and the deep basin very likely. This is supported by the present mobility of these deposits over a two-meter thick carpet on the outer shelf (Bassetti et al., 2006), as well as by the occurrence of sands of similar composition in the head of the BC (Gaudin et al., 2006) and the CCC (Degeest, 2005). Winter dense water cascading events, associated with enhanced bottom sediment transport (velocities up to $80 \mathrm{~cm} . \mathrm{s}^{-1}$ ) during eastern storms (Palanques et al., 2006), provide the energy required to transfer sand from the outer shelf into the canyon heads. Further evidence of high energetic conditions favouring sediment transport and erosion in the CCC (Canals et al., 2006; Lastras et al., 2007a) demonstrate the role of canyons as an efficient pathway for sediment towards the deep basin, even during high sea-level and when canyons are disconnected from rivers.

Heavy mineral assemblages revealed a significant contribution of the Pyrenean rivers in beds \#2, 3, 5 and 7 which are also dominantly located in the south eastern part of the area. As offshore sands are also present on the narrower shelf of the Catalan margin between the CCC and the LFC (Palamós) (Ercilla et al., 1995; Got and Aloïsi, 1990), these may also undergo periodical reworking and transfer into the LFC. Furthermore, the closeness of the LFC head and the Ter River mouth may, in addition, favour a rapid delivery of fluvial Pyrenean sediment into this canyon and explain that a Pyrenees signature is detected in some coarse beds. In the LFC, bottom velocities, reaching more than $20 \mathrm{~cm} . \mathrm{s}^{-1}$, have been measured (Palanques et al., 2005). Although lower than the theoretical threshold $\left(28 \mathrm{~cm} . \mathrm{s}^{-1}\right)$ required for the motion of sand under a unidirectional current (Miller et al., 1977), local accelerations of the flows can be envisaged at abrupt changes of slope (e.g. scours) or narrowing of the canyon course similar to that described in the CCC (Lastras et al., 2007b).

\subsection{Dispersal of the silt-sand material into the deep basin (Fig. 7)}

Two sediment cores (MD99-2344 and MAKS00-18) are crucial to decipher several dispersal sources because they are located on the top of the right levee (MD99-2344) and on the internal flank of the left levee of the Petit-Rhône neofan (MAKS00-18) (Fig. 3). Core MD992344 contains beds \#4, 6, 8, 9, 10, 11 and 12 while core MAKS00-18 does not contain any coarse bed. In this latter core, the onset of the hemipelagic drape is dated at $9260{ }^{14} \mathrm{C} \mathrm{yr} \mathrm{BP}$ (Fig. 4) showing a gap of $8500 \mathrm{cal}$. yr concomitant with beds \#12 to \#6. Deposition on top of the right levee hence has a correspondence as by-pass or/and severe erosion close to the channel bottom which suggests that the Petit-Rhône turbiditic neochannel still underwent sedimentary transit and possibly associated leveed, although coarse, spillover deposits. To 
the north, large furrows in the prolongation of the neochannel, in a tight meander (cf. Bonnel et al. (2005) their Fig. 3), suggest that the basal part (i.e. coarse) of energetic turbiditic currents must have crossed the levee and spread on the right levee. Bed \#4, on top of the right hand side levee (MD99-2344), is not recorded in the hemipelagic drape of the inner lefthand side levee (MAKS00-18), which also does not show evidence of erosion during the corresponding time interval, suggesting that the neochannel did not convey the sediment of this bed. The same interpretation applies to beds \#1, 2, 3 and 5, which are also absent from areas close to the Petit-Rhône turbiditic channel, again supporting the hypothesis of alternative dispersal sources. On the other hand, bed \#10 occurs inside the Petit-Rhône abandoned turbiditic channel (core KSGC-14), and on the outer levee, upstream (core KGMO-10) and downstream (core MD99-2344) the avulsion point. Bed \#7 occurs only next to the Petit-Rhône turbiditic channel upstream the avulsion point (core KGMO-10) and at the distal part of neochannel (core MD01-2437). This demonstrates that the coarse material of these beds was dispersed from the PRC. Thus, the PRC has most probably conveyed the material from beds \#6, 7, 8, 9, 10, 11 and 12 while material of beds \#1, 2, 3, 4 and 5, which are found only on the western part of the area, was dispersed from another source. Other possible dispersal points are the canyons west of the PRC (CCC, LDC, PC, BC, HC, SC and $\mathrm{MC}$ ) that converge to one outlet called the Sète canyon network, and the LFC (Fig. 1). The Sète Canyon network is a good candidate for beds \#1 and 4 according to their location and to their heavy mineral assemblage (Fig. 1). The LFC, separated from the Sète canyon network by the Cap de Creus promontory, is the most probable dispersal source for beds \#2, 5 and maybe bed \#3 considering their Pyrenean heavy mineral assemblage. The likely homogeneous heavy mineral assemblages of offshore sands, together with the convergence of the canyons in the deep basin does not allow to distinguish individual contribution of canyons from the CCC to the MC. The location of the "Sète lobe" and "La Fonera lobe" identified on the base of acoustic backscatter (Droz et al., 2001) also supports the dispersal pattern and the distribution pattern shown by core and geotechnical data.

\subsection{Depositional and erosive processes, role of scours}

The erosional bases, dominantly normal grading with horizontal lamination and/or climbing ripples in the silt-sand layers, are criteria for deposition by a waning flow and correspond to a top cut Bouma turbiditic sequence (Droz et al., 2001). Massive or poorly graded sand corresponds to the freezing of a laminated concentrated flow (Mulder and Alexander, 2001) (Term $\mathrm{Ta}$ of the Bouma sequence). Graded laminated and cross-laminated deposits correspond to deposition by the turbulent upper part of a flow (Terms Tb and Tc of the Bouma sequence, respectively).

The patchiness of the coarse beds, their variable thickness and erosional base, as well as the evidence for post-glacial erosion and sediment by-pass over the area witness rather unconfined flows and complex interaction between coarse sediment transport and seabed morphology. In the depressions, sandy layers are less abundant and tend to be coarser than on the highs (Figs. 5, 9 and 10). This suggests that the currents transporting the sand, although dominantly unconfined, were locally guided by the scours and underwent local acceleration, leading to erosion, by-pass and local coarser deposits. Dispersal of silt-sand rich flow therefore likely occurred by splitting into several flows, possibly funneled by the giant scours. The scours, either irregular to crescentic at the most distal reaches of the SC, giant and amalgamated at the foot of the Petit-Rhône neofan, or clustered spoon shaped in the distal part of the area, hence played an important role in the dispersal of silt-sand flows.

The post-glacial erosion, hiatus and deposition described in the giant scours (Fig. 9), hence, probably correspond to a reshaping and/or rejuvenation during changes of silt-sand flow characteristics (thickness, velocity) from the SC when they undergo hydraulic jumps. The variability of the age of the base of the hemipelagic drape at a kilometric scale, from 11100 to 500 cal. yr BP (Fig. 3), shows that areas of erosion and deposition have moved through time. Noteworthy, the lack of hemipelagic drape before $11100 \mathrm{cal}$. yr BP in the giant scours 
area, shows that prior to that time, this area underwent strictly erosive and/or non depositional processes since the end of turbiditic spillover from the neochannel at $18600 \mathrm{cal}$ $\mathrm{yr} \mathrm{BP}$, i.e. from the onset of the sea-level rise until about the end of the Younger Dryas (Fig. 14). There is no evidence whether these processes occurred during the whole of this period or during a shorter episode that eroded the sediment deposited from $18400 \mathrm{cal}$. yr BP onward. During the same period of time, the area next to the neochannel underwent deposition of hemipelagic drape and of silt-sand beds via the PRC. The neochannel (core MAKS00-18) underwent strictly erosive and/or non depositional processes until $10100 \mathrm{cal}$. yr. These observations show that between $18400 \mathrm{cal}$. yr BP and $11100 \mathrm{cal}$. yr BP, numerous sedimentary events occurred (7 depositional events in $7.5 \mathrm{ka}$ ), and that the siltsand by-passed the deepest part of the study area and was only deposited on turbiditic levees by spillover from the Petit-Rhône turbiditic channel (core KGMO-10) and neochannel (core MD99-2344). After $11100 \mathrm{cal}$ yr BP, sedimentary processes became dominantly depositional and dispersal from the Petit-Rhône turbiditic channel stopped.

\subsection{Controls on the exportation of coarse material into the deep basin}

The periodic deposition of coarse beds, as well as the long post-glacial hiatuses of deposition discussed above, are controlled by several mechanism acting at different time scales such as:

the sea-level rise, and related changes in the distance between the shoreline and canyon heads and possible connection with rivers,

the outer shelf hydro-sedimentary dynamics including the formation and the mobility of outer shelf transgressive and high stand deposits, and the reworking of regressive and low stand offshore sands,

periods of energy enabling sand transport into the canyons (possibly dense water downwelling)

the capability of canyons to store sediments.

Sea-level is the main controlling factor of the exportation of sediment into the deep basin as it controls the position of the sediment on the shelf and connections/disconnection of rivers and canyons. This is remarkably displayed in our study area by the concomitance of the end of river fed leveed turbiditic facies (our sedimentary facies 5 ) on the neofan, and the onset of the sea-level rise around $18400 \mathrm{cal}$. yr BP (Bonnel et al., 2005) (Fig. 14).

Once the direct delivery of river sediment into the canyon was cut, the main source of sediment became the sediment stock available on the outer shelf. This change in sediment sources probably closely follows the flooding of the canyon heads. The timing of the flooding of the canyon heads can be estimated by reporting the water depth of the canyons head wall on sea level curves (Camoin et al., 2004; Fairbanks, 1989; Hanebuth et al., 2000). Fifteen metres of subsidence at the outershelf, which accounts for the present water load (Jouet et al., 2008; Lambeck and Bard, 2000) and thermal cooling (Jouet et al., 2008; Rabineau et al., 2006) between 20000 and 15000 cal. yr BP, must be subtracted from the present water depth. The timing of the flooding of canyons heads is comprised between ca.18 $000 \mathrm{cal}$. $\mathrm{yr}$ $\mathrm{BP}$ and $13000 \mathrm{cal}$. yr BP (Fig. 14). Therefore, the end of direct input of Rhône sediments into the PRC occurred at about 17000 cal. yr BP (Fig. 14), $1500 \mathrm{yr}$ after the end of river fed spillover deposits at the neofan. After that time, the Rhone River was no longer connected to its canyon head. Nevertheless, the very frequent deposition of coarse beds (\#12, \#11, \#10, \#9 and \#8) via the Petit-Rhône turbiditic system, even after the flooding of the PRC head (Fig. 14) suggests the presence of a significant amount of sand in or close to the canyon head. This is further supported by (1) the occurrence of post-glacial sedimentary bodies, interpreted as last glacial alluvial deposits, close to the PRC head (Gensous and Tesson, 2003; Marsset and Bellec, 2002) and (2) by the dominantly "Alps" and absence of "Pyrenees" signature of heavy minerals in these beds. The abrupt landward shift of the shoreline at about 15000 cal. yr BP (Jouet et al., 2006) likely outpaced the progradation of the Petit- 
Rhône prodelta, hence preventing the deposition of shoreface sands into the canyon head and inhibiting their frequent transfer into the deep basin. The change in the frequency of deposition of silt-sand beds (\#7 to \#1) and the end of the predominance of erosive processes in the deep basin followed the complete flooding of the canyon heads and was concomitant with the deposition of backstepping transgressive prodeltaic deposits on the central-inner shelf (Berné et al., 2007), and the formation of sand ridges (Younger Dryas) and dunes (Holocene) reworking regressive deposits on the outer shelf (Bassetti et al., 2006) (Fig. 14). As a result, sedimentation on the continental rise, initially controlled by the river regime, became dependant upon shelf edge hydro-dynamical processes. As a result, the source of sediment became further influenced by the western part of the Gulf of Lions, increasing the fraction of Pyrenean heavy minerals in sand-silt beds (Tab. 3). The lack of coarse spillover deposits from the Petit-Rhône turbiditic channel since bed \#6 (10300 cal. yr BP) suggests that during the Holocene, outer shelf hydro-dynamical processes and sediment transport were more vigorous along the Sète network canyon heads than at the PRC head. This outline is also drawn by the present sedimentary fluxes and transport processes that show that the most energetic processes occur in canyons of the western Gulf of Lions (Heussner et al., 2006; Palanques et al., 2006 ).

Strong currents measured at the PRC $\left(48 \mathrm{~cm} \cdot \mathrm{s}^{-1}\right.$ at $1800 \mathrm{~m}$ water depth; Millot and Monaco, 1984), LDC (60 cm.s ${ }^{-1}$ at $1000 \mathrm{~m}$; Heussner et al., 2006) and CCC (85 cm.s-1 at $750 \mathrm{~m}$; Canals et al., 2006) likely favour along-canyon transport of coarse material on a seasonal basis. It also likely favours its storage downstream, as shown by the non-penetrative echo facies in the lower course of the SC, CCC and LFC (Droz et al., 2001; Lastras et al., 2007a). The periodicity of deposition of silt-sand beds, about $500 \mathrm{yr}$ from bed \#12 to \#8 and about 2 $000 \mathrm{yr}$ from bed \#7 to \#1 is beyond the present seasonal variability recorded for sediment transport on the shelf and in the canyons and beyond the pluri-annual variability of the major cascading of dense water that exports large amounts of sediment, including sand, into the canyons (Canals et al., 2006; Gaudin et al., 2006). This shows that canyons act as a very efficient sediment trap that undergo periodical flushing at centennial and millennial scales. Primary controls on the rate of flushing are the volume of sediment input, the storage capability in the canyon, acting as a buffer, and trigger mechanisms. The convergence of the Sète canyon network does not allow discriminating inputs from individual canyons. This is only constrained at the PRC who has not dispersed coarse material since bed \#6 (10 316 cal. yr BP), indicating lower sediment input than in the Sète canyon network during the Holocene. However, the true exit of the PRC is located slightly outside the study area at the termination of neochannel and dispersal of sand may still occur further south. Detailed investigation of the CCC unveiled evidence of sand layers in the canyon head down to 300$400 \mathrm{~m}$ water depth (Degeest, 2005), as well as pervasive bedforms such as kilometric scale furrows, mid-channel bars, sandy lag deposits and scours. Although these may be relicts from the last glacial maximum, their fresh state is still indicative of present vigorous erosive bottom current and bed load transport (Lastras et al., 2007a). Evidence of sand storage is also found in the BC2 head (Gaudin et al., 2006) and is suspected in LDC because of the concomitance of very large sand dunes (Berné et al., 2001) and very high bottom shear stress during easterlies (Bassetti et al., 2006). The lack of detailed investigation along the canyons does not allow to conclude on the amount of sand presently stored throughout canyon network.

The trigger mechanism enabling the transport of sand into the deep basin remains speculative. It may rely on direct supply related to extreme events of cascading cold water involving the formation of cascadites (Gaudin et al., 2006). These processes may not be restricted to the canyon heads but propagate along the thalweg, evolving into turbidity current as shown by the grading and sedimentary structures in the coarse layers. The periodic deposition of silt-sand beds outlines a periodic flushing either by liquefaction failure or by retrogressive (breaching) failure (Van Den Berg et al., 2002) such as in the Scripps canyon (Mastbergen and Van Den Berg, 2003). Breaching is presented as the most efficient mechanism for removing huge amounts of sand (Mastbergen and Van Den Berg, 2003). 
However, the sedimentary structures in silt-sand layers do not allow to discriminate between breaching and liquefaction.

The origin of the periodicity of the turbidites remains speculative. Contrarily to what is described in modern systems such as in the north-west African abyssal plains (Weaver and Kuijpers, 1983; Weaver et al., 1992; Wynn et al., 2002b) and in the Balearic Abyssal Plain (Rothwell et al., 2006), or in fossil systems (Marjanac, 1996), the periodicity of turbidites does not change with the rate of sea level changes, suggesting no direct control on the trigger mechanisms such as slope failure (Maslin et al., 2004). However, no periodical external forcing (e.g. periods of enhanced storms) is actually needed. Flushing may be triggered by winter storms or canyon wall instability once accumulation in the canyon has reached a threshold and has become sub-stable. Furthermore, and speculatively, flushing may also be correlated to known post-glacial climatic variability such as the $2000 \mathrm{yr}$ variability of El Niño/Southern Oscillation (ENSO) (Moy et al., 2002) or the $900 \mathrm{yr}$ periodicity of Greenland temperatures (Schulz and Paul, 2002).

\section{Conclusions}

The detailed investigation of the last glacial and post-glacial deposits at the Rhône deep-sea turbiditic system lead to the following conclusions:

High accumulation rate of river fed turbiditic spillover deposits at the Petit-Rhône turbiditic system stopped around $18400 \mathrm{cal}$. yr BP, i.e. at the onset of sea-level rise. This implies that direct delivering of Rhone River sediment load to the PRC stopped at that time, giving rise to the initiation of an early transgressive shelf-edge delta.

Exportation of coarse material through the PRC and turbiditic channel continued from that time until $15600 \mathrm{cal}$. yr BP, probably fed by the destabilization/mobility of sandy coastal deposits at the canyon head, at a periodicity of about $500 \mathrm{yr}$ (beds \#12 to \#8).

Concomitantly, the area to the southwest of the Petit-Rhône neochannel, at the outlet of the Sète canyon network, underwent erosive/by-pass processes until $11100 \mathrm{cal}$. yr BP.

The complete flooding of the canyon heads at about $13000 \mathrm{cal}$. yr BP, until the present time, lead to less frequent exportation of coarse deposits (periodicity about $2000 \mathrm{yr}$ ).

Transgressive deposits reworked from relict offshore sand of the outer shelf are the source of the silt-sand exported into the deep basin since $13000 \mathrm{cal}$. yr BP.

Less vigourous hydrodynamical processes at the PRC head (compared to the western Gulf of Lions) prevented the dispersal of coarse material in the deep basin from the PRC since 10 300 cal. yr BP.

Strong seasonal hydrodynamical processes, such as cascading of dense water, can provide the energy for exporting these sands into the canyons down to the continental rise.

Our study demonstrates that exportation of sand into the deep basin via the canyon drainage network can persist during a sea level rise and high stand. However, the sea level rise does not directly force this turbiditic activity via slope instability for instance, but it is the flooding of the margin that creates the conditions at the outer shelf for strong seasonal hydrodynamics necessary for the reworking of sand relicts.

\section{Acknowledgements}

We should like to thank the technical staff from IFREMER (René Kerbrat, Gilbert Floch, Mickael Rovere, Ronan Apprioual, Nelly Frumholz, Jean-Yves Landuré, François Harmenies, Philippe Dorval) for the data acquisition and processing. Foraminifera picking for AMS radiocarbon dating was performed at the Université de Sfax (Tunisia). Radiocarbon dating was performed at the Poznan Radiocarbon Laboratory (Poland). We thank the crews and scientific teams of cruises "MD114-ImagesV" and "MD123-Geosciences1" (R/V Marion 
Dufresne), "Marion", "GMO" and "GMO2-CARNAC" (R/V Le Suroît). This study was supported by Ifremer, by the French national programme "GDR Marges", the "URM17" research group, by the Framework Programme 5 European project "Eurostrataform" (contract \#EVK3-CT-2002-00079) by the French Agence Nationale de la Recherche (ANR "Sesame", contract NT05-3-42040 and ANR "EXTREMA", contract N ANR-06-VULN-005). Fruitful comments from two anonymous reviewers and Editor $\operatorname{Dr}$ D.J.W. Piper helped to greatly improve the manuscript. Alison Chalm is warmly thanked for improving the English.

\section{References}

Aloïsi, J.-C., 1986. Sur un modèle de sédimentation deltaïque. Contribution à la connaissance des marges passives. Unpublished Doctoral Thesis, University of Perpignan, Perpignan, France, 162 pp.

Auffret, G., Zaragosi, S., Dennielou, B., Cortijo, E., Van Rooij, D., Grousset, F., Pujol, C., Eynaud, F., Siegert, M., 2002. Terrigenous fluxes at the Celtic margin during the last glacial cycle. Mar. Geol. 188, 79-108.

Baltzer, A., Cochonat, P., Piper, D.J.W., 1994. In situ geotechnical characterization of sediments on the Nova Scotian Slope, eastern Canadian continental margin. Mar. Geol. 120, 291-308.

Bassetti, M.A., Jouet, G., Dufois, F., Berné, S., M., R., Taviani, M., 2006. Sand bodies at the shelf edge in the Gulf of Lions (Western Mediterranean): Deglacial history and modern processes. Mar. Geol. 234, 93-109.

Baztan, J., Berné, S., Olivet, J.-L., Rabineau, M., Aslanian, D., Gaudin, M., Réhault, J.-P., Canals, M., 2005. Axial incision, the key to understand submarine canyon evolution (in the western gulf of Lion). Mar. Pet. Geol. 22, 805-806.

Beaudouin, C., Dennielou, B., Melki, T., Guichard, F., Kallel, N., Berne, S., Huchon, A., 2004. The Late-Quaternary climatic signal recorded in a deep-sea turbiditic levee (Rhone Neofan, Gulf of Lions, NW Mediterranean): palynological constraints. Sediment. Geol. 172, 85-97.

Bellaiche, G., Thiriot-Quievreux, C., 1982. The origin and significance of a thick deposit of pteropod shells in the RhÙne deep sea fan. Paleogeogr. Paleoclimatol. Paleoecol. 39, 129137.

Berné, S., Carré, D., Loubrieu, B., Mazé, J.-P., Normand, A., 2001. Carte morphobathymétrique du Golfe du Lion. Ifremer-Région Languedoc-Roussillon, Brest.

Berné, S., Jouet, G., Bassetti, M.A., Dennielou, B., Taviani, M., 2007. Late Glacial to Preboreal sea-level rise recorded by the Rhone deltaic system (NW Mediterranean). Mar. Geol. 245, 65-88.

Berné, S., Lericolais, G., Marsset, T., Bourillet Jean, F., De Batist, M., 1998. Erosional shelf sand ridges and lowstand shoreface: examples from tide and wave dominated environments of France. J. Sediment. Res. 68, 540-555.

Berné, S., Loubrieu, B., embarquée, I.E.C., 1999. Canyons et processus sédimentaires récents sur la marge occidentale du Golfe du Lion. Premiers résultats de la campagne Calmar. C.R. Acad. Sci. Series IIA 328, 471-477.

Bonnel, C., Dennielou, B., Berné, S., Mulder, T., Droz, L., 2005. Architecture and depositional pattern of the Rhône Neofan and recent gravity activity in the Gulf of Lions (Western Mediterranean). Mar. Pet. Geol. 22, 827-843.

Bourcart, J., 1945. Etude des sédiments pliocènes et quaternaires du Roussillon. Bull. Serv. Carte Géol. France 45, 395-476.

Camoin, G.F., Montaggioni, L.F., Braithwaite, C.J.R., 2004. Late glacial to post glacial sea levels in the Western Indian Ocean. Mar. Geol. 206, 119-146.

Canals, M., Puig, P., Durrieu de Madron, X., Heussner, S., Palanques, A., Fabres, J., 2006. Flushing submarine canyons. Nature 444, 354-355. 
Degeest, A.L., 2005. Cap de Creus: A link between shelf and slope sediment dispersal systems in the Gulf of Lions, France. Master of Science Thesis, Texas A\&M University, College Station, $85 \mathrm{pp}$.

Dennielou, B., Huchon, A., Beaudouin, C., Berné, S., 2006. Vertical grain-size variability within a turbidite levee: Autocyclicity or allocyclicity? A case study from the Rhone neofan, Gulf of Lions, Western Mediterranean. Mar. Geol. 234, 191-213.

dos Reis, A.T., Gorini, C., Mauffret, A., Mepen, M., 2004. Stratigraphic architecture of the Pyreneo-Languedocian submarine fan, Gulf of Lions, western Mediterranean Sea. Comptes Rendus Geosciences 336, 125-133.

Droz, L., 1983. L'éventail sous-marin profond du Rhône (Golfe du lion) : grands traits morphologiques et structure semi-profonde. PhD Thesis, Université Paris VI, Paris, 195 pp.

Droz, L., Bellaiche, G., 1985. Rhone Deep-Sea Fan: morphostructure and growth pattern. American Association of Petroleum Geologists Bulletin 69, 460-479.

Droz, L., Kergoat, R., Cochonat, P., Berné, S., 2001. Recent sedimentary events in the western Gulf of Lions (Western Mediterranean). Mar. Geol. 176, 23-37.

Droz, L., Reis, A.T.d., Rabineau, M., Berné, S., Bellaiche, G., 2006. Quaternary turbidite systems on the northern margins of the Balearic Basin (Western Mediterranean): a synthesis. Geo-Mar. Lett. 26, 347-359.

Duplaix, S., 1972. Les minéraux lourds de sables de plages et de canyons sous-marins de la Méditerranée française. In: S. D.J. (Editor), The Mediterranean Sea. Dowden Hutchinson \&, Stroudsburg, pp. 293-303.

Duplaix, S., Lalou, C., 1951. Etude pétrologique des sables du Roussillon. Vie et Millieu 2, 501-527.

Ercilla, G., Diaz, J.I., Alonso, B., Farran, M., 1995. Late Pleistocene-Holocene sedimentary evolution of the Northern Catalonia continental shelf (northwestern Mediterranean Sea. Cont. Shelf Res. 15, 1435-1451.

Fairbanks, R.G., 1989. A 17,000 year glacio-eustatic sea level record: Influence of glacial melting rates on the Younger Dryas and deep sea circulation. Nature 342, 637-342.

Flood, R.D., Piper, D.J.W., 1997. Amazon fan sedimentation: the relationship to equatorial climate change, continental denudation, and sea-level fluctuations. Proceedings of the Ocean Drilling Program, Scientific Results, 155. Ocean Drilling Program, College Station, TX, 653-675 pp.

Gaudin, M., Berné, S., Jouanneau, J.-M., Palanques, A., Puig, P., Mulder, T., Cirac, P., Rabineau, M., Imbert, P., 2006. Massive sand beds attributed to deposition by dense water cascades in the Bourcart canyon head, Gulf of Lions (northwestern Mediterranean Sea). Mar. Geol. 234, 111-128.

Gaullier, V., Antonini, E., Benkhelil, J., Got, H., 1998. Recent gravity-driven sedimentary bodies in the North-Balearic Basin: geometry and quantification. C.R. Acad. Sci. Series IIA 327, 677-684.

Gensous, B., Tesson, M., 2003. L'analyse des dépôts postglaciaires et son application à l'étude des séquences de dépôts du Quaternaire terminal sur la plate-forme au large du Rhône (golfe du Lion). Bull. Soc. Géol. de France 174, 401-419.

Goldfinger, C., Nelson, C.H., Johnson, J.E., Party, S.S., 2003. Deep-water turbidites as Holocene earthquake proxies: the Cascadia subduction zone and Northern San Andreas Fault systems. Annals of Geophysisc 46, 1169-1194.

Got, H., Aloïsi, J.-C., 1990. The Holocene sedimentation on the Gulf of Lions margin: a quantitative approach. Cont. Shelf Res. 10, 841-855.

Hanebuth, T., Stattegger, K., Grootes, P.M., 2000. Rapid Flooding of the Sunda Shelf: A Late-Glacial Sea-Level Record. Science 288, 1033-1035.

Heussner, S., Durrieu de Madron, X., Calafat, A., Canals, M., Carbonne, J., Delsaut, N., Saragoni, G., 2006. Spatial and temporal variability of downward particle fluxes on a continental slope: Lessons from an 8-yr experiment in the Gulf of Lions (NW Mediterranean). Mar. Geol. 234, 63-92. 
Hieke, W., Werner, F., 2000. The Augias megaturbidite in the central Ionian Sea (central Mediterranean) and its relation to the Holocene Santorini event. Sediment. Geol. 135, 205218.

Hughen, K., Baillie, M., Bard, E., Bayliss, A., Beck, J., Bertrand, C., Blackwell, P., Buck, C., Burr, G., Cutler, K., Damon, P., Edwards, R., Fairbanks, R., Friedrich, M, G., TP,, Kromer, B., McCormac, F., Manning, S., Bronk Ramsey, C., Reimer, P., Reimer, R., Remmele, S., Southon, J., Stuiver, M., Talamo, S., Taylor, F., van der Plicht, J., Weyhenmeyer, C., 2004. Marine04 Marine radiocarbon age calibration, 26 - 0 ka BP. Radiocarbon 46, 1059-1086.

Jallet, L., Giresse, P., 2005. Construction of the Pyreneo-Languedocian Sedimentary Ridge and associated sediment waves in the deep western Gulf of Lions (Western Mediterranean). Mar. Pet. Geol. 22, 865-888.

Jouet, G., Berne, S., Rabineau, M., Bassetti, M.A., Bernier, P., Dennielou, B., Sierro, F.J., Flores, J.A., Taviani, M., 2006. Shoreface migrations at the shelf edge and sea-level changes around the Last Glacial Maximum (Gulf of Lions, NW Mediterranean). Mar. Geol. 234, 21-42.

Jouet, G., Hutton, E.W.H., Syvitski, J.P.M., Berné, S., 2008. Response of the Rhône deltaic margin to loading and subsidence during the last climatic cycle. Computer and Geosciences 34, 1338-1357.

Kenyon, N.H., Millington, J., Droz, L., Ivanov, M.K., 1995. Scour holes in a channel-lobe transition zone on the Rhône cone. In: K.T. Pickering, R.N. Hiscott, N.H. Kenyon, F.R. Lucchi and R.D.A. Smith (Editors), Atlas of Deep-water Environments: Architectural Styles in Turbidite Systems. Chapman and Hall, London, pp. 212-215.

Labaune, C., Jouet, G., Berne, S., Gensous, B., Tesson, M., Delpeint, A., 2005. Seismic stratigraphy of the Deglacial deposits of the Rhone prodelta and of the adjacent shelf. Mar. Geol. 222-223, 299-311.

Lambeck, K., Bard, E., 2000. Sea-level change along the French Mediterranean coast for the past 30000 years. Earth Planet. Sci. Lett. 175, 203-222.

Lastras, G., Canals, M., Urgeles, R., Amblas, D., Ivanov, M., Droz, L., Dennielou, B., Fabres, J., Schoolmeester, T., Akhmetzhanov, A., Orange, D., Garcia-Garcia, A., 2007a. A walk down the Cap de Creus canyon, Northwestern Mediterranean Sea: Recent processes inferred from morphology and sediment bedforms. Mar. Geol. 246, 176-192.

Lastras, G., Canals, M., Urgeles, R., Amblas, D., Ivanov, M., Droz, L., Dennielou, B., Fabrés, J., Schoolmeester, T., Akhmetzhanov, A., Orange, D., Garcia-Garcia, A., 2007b. A walk down the Cap de Creus canyon, northwestern Mediterranean Sea: Recent processes inferred from morphology and sediment bedforms. Mar. Geol. 246, 176-192.

Lebreiro, S.M., McCave, I.N., Weaver, P.P.E., 1997. Late Quaternary turbidite emplacement on the Horseshoe abyssal plain (Iberian margin). J. Sediment. Res. 67, 856-870.

Lofi, J., Weber, O., 2001. SCOPIX - digital processing of X-ray images for the enhancement of sedimentary structures in undisturbed core slabs. Geo-Mar. Lett. 20, 182-186.

Marjanac, T., 1996. Deposition of megabeds (megaturbidites) and sea-level change in a proximal part of the Eocene-Miocene flysch of central Dalmatia (Croatia). Geology 24, 543546.

Marsset, T., Bellec, V., 2002. Late Pleistocene-Holocene deposits of the Rhône inner continental shelf (France) : detailed mapping and correlation with previous continental and marine studies. Sedimentology 49, 255-276.

Maslin, M., Owen, M., Day, S., Long, D., 2004. Linking continental-slope failures and climate change: Testing the clathrate gun hypothesis. Geology 32, 53-56.

Mastbergen, D.R., Van Den Berg, J.H., 2003. Breaching in fine sands and the generation of sustained turbidity currents in submarine canyons. Sedimentology 50, 625-637.

Méar, Y., 1984. Séquences et unités sédimentaires du glacis rhôdanien (Méditerranée occidentale). PhD Thesis, Perpignan.

Méar, Y., Gensous, B., 1993. Processus d'édification d'une unite interlobe; application au deep-sea fan du Petit-Rhône. C.R. Acad. Sci. Serie II 317, 1633-1640.

Migeon, S., Weber, O., Faugères, J.-C., Saint-Paul, J., 1999. SCOPIX: A new X-ray imaging system for core analysis. Geo-Mar. Lett. 18, 251-255. 
Miller, M.C., McCave, I.N., Komar, P.D., 1977. Threshold of sediment motion under unidirectional currents. Sedimentology 24, 507-527.

Millot, C., 1991. Mesoscale and seasonal variabilities of the circulation in the Western Mediterranean. Dyn. Atmos. Oceans 15, 179-214.

Monaco, A., 1971. Contribution à l'étude géologique et sédimentologique du plateau continental d Roussillon (Golfe du Lion). Thèse d'état Thesis, Université des Sciences et Techniques du Languedoc, Perpignan, $295 \mathrm{pp}$.

Moy, C.M., Seltzer, G.O., Rodbell, D.T., Anderson, D.M., 2002. Variability of El Nino/Southern Oscillation activity at millennial timescales during the Holocene epoch. Nature 420, 162-165.

Mulder, T., Alexander, J., 2001. The physical character of subaqueous sedimentary density flows and their deposits. Sedimentology 48, 269-299.

Normark, W.R., Piper, D.J.W., Hiscott, R.N., 1998. Sea level controls on the textural characteristics and depositional architecture of the Hueneme and associated submarine fan systems, Santa Monica basin, California. Sedimentology 45, 53-70.

Palanques, A., Durrieu de Madron, X., Puig, P., Fabres, J., Guillen, J., Calafat, A., Canals, M., Heussner, S., Bonnin, J., 2006. Suspended sediment fluxes and transport processes in the Gulf of Lions submarine canyons. The role of storms and dense water cascading. Mar. Geol. 234, 43-61.

Palanques, A., Garcia-Ladona, E., Gomis, D., Martin, J., Marcos, M., Pascual, A., Puig, P., Gili, J.-M., Emelianov, M., Monserrat, S., Guillen, J., Tintore, J., Segura, M., Jordi, A., Ruiz, S., Basterretxea, G., Font, J., Blasco, D., Pages, F., 2005. General patterns of circulation, sediment fluxes and ecology of the Palamos (La Fonera) submarine canyon, northwestern Mediterranean. Progress In Oceanography 66, 89-119.

Prins, M.A., Postma, G., Cleveringa, J., Cramp, A., Kenyon, N.H., 2000a. Controls on terrigenous sediment supply to the Arabian Sea during the late Quaternary: the Indus Fan. Mar. Geol. 169, 327-349.

Prins, M.A., Postma, G., Weltje, G.J., 2000b. Controls on terrigenous sediment supply to the Arabian Sea during the late Quaternary: the Makran continental slope. Mar. Geol. 169, 351371.

Rabineau, M., Berne, S., Ledrezen, E., Lericolais, G., Marsset, T., Rotunno, M., 1998. 3D architecture of lowstand and transgressive Quaternary sand bodies on the outer shelf of the Gulf of Lion, France. Mar. Pet. Geol. 15, 439-452.

Rabineau, M., Berne, S., Olivet, J.-L., Aslanian, D., Guillocheau, F., Joseph, P., 2006. Paleo sea levels reconsidered from direct observation of paleoshoreline position during Glacial Maxima (for the last 500,000 yr). Earth Planet. Sci. Lett. 252, 119-137.

Ramsey, N., Year. A calibrated model for the interpretation of cone penetration tests (CPTs) in North Sea quaternary soils, Proceedings of Offshore Site Investigation and Geotechnics: diversity and sustainability, London, pp. 341-356.

Rothwell, R.G., Hoogakker, B., Thomson, J., Croudace, I.W., Frenz, M., 2006. Turbidite emplacement on the southern Balearic Abyssal Plain (western Mediterranean Sea) during Marine Isotope Stage 1-3: an application of ITRAX XRF scanning of sediment cores to lithostratigraphical analysis. In: R.G. Rothwell (Editor), New Techniques in Sediment Cores Analysis. Special Publications. Geological Society, London, pp. 79-98.

Rothwell, R.G., Thomson, J., Kähler, G., 1998. Low-sea-levelemplacement of a very large Late Pleistocene 'megaturbidite' in the western Mediterranean Sea. Nature 392, 377-380.

Schulz, M., Paul, A., 2002. Holocene Climate Variability on Centennial-to-Millennial Time Scales: 1. Climate Records from the North-Atlantic Realm. In: G. Wefer, W.H. Berger, K.-E. Behre and E. Jansen (Editors), Climate Development and History of the North Atlantic Realm. Springer-Verlag, Berlin Heidelberg, pp. 41-54.

Shanmugam, G., Moiola, R.J., Damuth, J.E., 1985. Eustatic control of submarine fan development. In: A.H. Bouma, N.E. Barnes and W.R. Normark (Editors), Submarine fans and related turbidite systems. Springer Verlag, NewYork, pp. 23-28.

Shepard, F.P., 1954. Nomenclature based on sand-silt-clay ratios, J. Sediment. Petrol., pp. 151-158. 
Shipboard-Scientific-Party, 1995. Explanatory notes. In: R.D. Flood, D.J.W. Piper, A. Klaus and L.C. Peterson (Editors), Proceedings of the Ocean Drilling Program, Initial Reports. Ocean Drilling Program, College Station, TX, pp. 47-81.

Skinner, L.C., McCave, I.N., 2003. Analysis and modelling of gravity- and piston coring based on soil mechanics. Mar. Geol. 199, 181-204.

Stow, D.A.V., Piper, D.J.W., 1984. Deep-water fine-grained sediments: facies models. In: D.A.V. Stow and D.J. Piper (Editors), Fine-Grained sediments: Deep-Water processes and Facies. Blackwell Scientific Publications, pp. 612-646.

Stuiver, M., Reimer, P.J., 1993. Extended 14C database and revised CALIB radiocarbon calibration program. Radiocarbon 35, 215-230.

Tesson, M., Gensous, B., Allen, G.P., Ravenne, C., 1990. Late Quaternary Lowstand Wedges on the Rhone Continental Shelf, France. Mar. Geol. 91, 325-332.

Torres, J., Droz, L., Savoye, B., Terentieva, E., Cochonat, P., Kenyon, N.H., Canals, M., 1997. Deep-sea avulsion and morphosedimentary evolution of the Rhône Fan Valley and Neofan during the Late Quaternary (north-western Mediterranean Sea). Sedimentology 44, 457-477.

Van Andel, T.H., 1955. Sediments of the Rhône delta, II. Source and deposits of heavy minerals. Koninklijk Nederladsch Geologisch Mijnbouwkundig Genootschap, Geologische serie XV 3, 353-356.

Van Den Berg, J.H., Van Gelder, A., Mastbergen, D.R., 2002. The importance of breaching as a mechanism of subaqueous slope failure in fine sand. Sedimentology 49, 81-95.

Vatan, A., 1949. Etude pétrographique des matériaux sableux côtiers du Golfe du Lion entre Cap Cerbère et l'Embouchure du Rhône, Proceedings of Congrès Sédimentation et Quaternaire, La Rochelle, pp. 147-156.

Weaver, P.P.E., Kuijpers, A., 1983. Climatic control of turbidite deposition on the Madeira Abyssal Plain. Nature 306, 360-363.

Weaver, P.P.E., Rothwell, R.G., 1987. Sedimentation on the Madeira Abyssal Plain over the last 300,000 years. In: P.P.E. Weaver and J. Thomson (Editors), Geology and Geochemistry of Abyssal Plains. Geol. Soc. London Spec. Publ., pp. 71-86.

Weaver, P.P.E., Rothwell, R.G., Ebbing, J., Gunn, D., Hunter, P.M., 1992. Correlation, frequency of emplacement and source directions of megaturbidites on the Madeira Abyssal Plain. Mar. Geol. 109, 1-20.

Weber, M.E., Wiedicke, M.H., Kudrass, H.R., bscher, C., Erlenkeuser, H., 1997. Active growth of the Bengal Fan during sea-level rise and highstand. Geology 25, 315-318.

Weber, M.E., Wiedicke-Hombach, M., Kudrass, H.R., Erlenkeuser, H., 2003. Bengal Fan sediment transport activity and response to climate forcing inferred from sediment physical properties. Sediment. Geol. 155, 361-381.

Wentworth, C.K., 1922. A scale of grade and class terms of clastic sediments. Journal of Geology 30, 377-392.

Wien, K., Holz, C., Kolling, M., Schulz, H.D., 2006. Age models for pelagites and turbidites from the Cap Timiris Canyon off Mauritania. Mar. Pet. Geol. 23, 337-352.

Wynn, R.B., Kenyon, N.H., Masson, D.G., Stow, D.A.V., Weaver, P.P.E., 2002a. Characterization and recognition of deep-water channel-lobe transition zones. Am. Assoc. Pet. Geol. Bull. 86, 1441-146.

Wynn, R.B., Weaver, P.P.E., Masson, D.G., 2002b. Turbidite depositional architecture across three interconnected deep-water basins on the north-west African margin. Sedimentology 49, 669-695.

Zaragosi, S., Auffret, G.A., Faugeres, J.-C., Garlan, T., Pujol, C., Cortijo, E., 2000. Physiography and recent sediment distribution of the Celtic Deep-Sea Fan, Bay of Biscay. Mar. Geol. 169, 207-237.

Zaragosi, S., Le Suavé, R., Bourillet, J.-F., Auffret, G., Faugères, J.-C., Pujol, C., Garlan, T., 2001. The deep-sea Armorican depositional system (Bay of Biscay), a multiple source, ramp model. Geo-Mar. Lett. 20, 219-232.

Zuniga, D., Garcia-Orellana, J., Calafat, A., Price, N.B., Adatte, T., Sanchez-Vidal, A., Canals, M., Sanchez-Cabeza, J.A., Masque, P., Fabres, J., 2007. Late Holocene fine- 
grained sediments of the Balearic Abyssal Plain, Western Mediterranean Sea. Mar. Geol. 237, 25-36. 
Tables

\begin{tabular}{|c|c|c|c|c|c|}
\hline Core & Sample & $\begin{array}{l}\text { Radiocarbon } \\
\text { age, yr BP }\end{array}$ & Calendar age, yr BP (1 sigma) & Material & Analyse \# \\
\hline \multirow[t]{12}{*}{ MD99-2344 } & $9-10 \mathrm{~cm}$ & $2680 \pm 40$ & [2 751-2796]; [2 825-2 842] & Globigerina bulloides & LLNL-73268 \\
\hline & $51-53 \mathrm{~cm}$ & $7060 \pm 40$ & [7 851-7 906]; [7 915-7 941] & Globigerina inflata & Poz-13811 \\
\hline & $93-95 \mathrm{~cm}$ & $9750 \pm 50$ & [11 162-11 232] & $\begin{array}{l}\text { Globigerina inflata and } \\
\text { Globigerinoides ruber }\end{array}$ & Poz-14632 \\
\hline & $144-145$ & $13595 \pm 35$ & [15 987-16 357] & Globigerina bulloides & LLNL-87504 \\
\hline & $\mathrm{cm}$ & & & & \\
\hline & $\begin{array}{l}157-160 \\
\mathrm{~cm}\end{array}$ & $14080 \pm 60$ & [16 591-16 993] & Globigerina bulloides & Poz-14633 \\
\hline & $172-174$ & $14390 \pm 70$ & {$\left[\begin{array}{lllll}17 & 046-17 & 503\end{array}\right]$} & Globigerina bulloides & Poz-14634 \\
\hline & $\mathrm{cm}$ & & & & \\
\hline & $\begin{array}{l}195-196 \\
\mathrm{~cm}\end{array}$ & $14800 \pm 35$ & [17 870-18 054] & Globigerina bulloides & LLNL-87505 \\
\hline & $215-216$ & $15010 \pm 40$ & [18 135-18 364]; [18 449-18 538] & Globigerina bulloides & LLNL-87506 \\
\hline & $\mathrm{cm}$ & & & & \\
\hline & $\begin{array}{l}230-232 \\
\mathrm{~cm}\end{array}$ & $15510 \pm 50$ & [18 224-18 308]; [18 484-18 654] & Globigerina bulloides & LLNL-73269 \\
\hline MAKS00-18 & $83-86 \mathrm{~cm}$ & $9260 \pm 50$ & {$\left[\begin{array}{lll}10 & 025-10 & 181\end{array}\right]$} & Globigerina inflata & Poz-14635 \\
\hline \multirow[t]{2}{*}{ KIGC-01 } & $4-6 \mathrm{~cm}$ & $1670 \pm 30$ & [1 202-1 271] & Globigerina inflata & Poz-13814 \\
\hline & $44-47 \mathrm{~cm}$ & $7030 \pm 40$ & [7 471-7 559] & Globigerina inflata & Poz-14599 \\
\hline \multirow[t]{2}{*}{ KIGC-02 } & $0-2 \mathrm{~cm}$ & $1365 \pm 30$ & {$[882-951]$} & Globigerina inflata & Poz-13815 \\
\hline & $8-11 \mathrm{~cm}$ & $4815 \pm 30$ & {$\left[\begin{array}{lll}5 & 038-5 & 139\end{array}\right] ;\left[\begin{array}{lll}5 & 145-5 & 195\end{array}\right]$} & $\begin{array}{l}\text { Globigerina bulloides } \\
\text { and Globigerina inflata }\end{array}$ & Poz-14600 \\
\hline \multirow[t]{2}{*}{ KIGC-03 } & $23-25 \mathrm{~cm}$ & $6960 \pm 40$ & {$\left[\begin{array}{llll}7 & 421-7 & 497\end{array}\right]$} & Globigerina inflata & Poz-14603 \\
\hline & $50-52 \mathrm{~cm}$ & $10100 \pm 50$ & [11 091-11 177] & Globigerina inflata & Poz-14602 \\
\hline KIGC-05 & $0-2 \mathrm{~cm}$ & $1135 \pm 30$ & {$[655-709]$} & Globigerina inflata & Poz-14604 \\
\hline \multirow[t]{4}{*}{ KIGC-07 } & $4-6 \mathrm{~cm}$ & $995 \pm 30$ & [548-615] & $\begin{array}{l}\text { Globigerina bulloides } \\
\text { and Globigerina inflata }\end{array}$ & Poz-14605 \\
\hline & $19-21 \mathrm{~cm}$ & $4705 \pm 35$ & [4 859-4 969] & Globigerina bulloides & Poz-14606 \\
\hline & $38-41 \mathrm{~cm}$ & $6860 \pm 50$ & {$\left[\begin{array}{llll}7 & 323-7 & 421\end{array}\right]$} & Globigerina inflata & Poz-14608 \\
\hline & $62-64 \mathrm{~cm}$ & $10000 \pm 50$ & [10 909-11 110] & Globigerina inflata & Poz-14609 \\
\hline \multirow[t]{2}{*}{ KSGC-11 } & $30-33 \mathrm{~cm}$ & $6675 \pm 35$ & {$\left[\begin{array}{llll}7 & 167-7 & 244\end{array}\right]$} & Globigerina inflata & Poz-14623 \\
\hline & $60-62 \mathrm{~cm}$ & $9830 \pm 50$ & {$\left[\begin{array}{llll}10 & 590-10 & 766\end{array}\right]$} & Globigerina inflata & Poz-14624 \\
\hline KSGC-10 & $1-2 \mathrm{~cm}$ & $840 \pm 30$ & {$[452-499]$} & Globigerina inflata & Poz-13817 \\
\hline \multirow[t]{8}{*}{ MD99-2345 } & $94-95 \mathrm{~cm}$ & $3540 \pm 35$ & [3 372-3 464] & $\begin{array}{l}\text { Globigerina bulloides } \\
\text { and Globigerina inflata }\end{array}$ & Poz-14636 \\
\hline & $115-117$ & $4370 \pm 35$ & [4 440-4 556] & Globigerina inflata & Poz-14637 \\
\hline & $\mathrm{cm}$ & & & & \\
\hline & $\begin{array}{l}161-163 \\
\mathrm{~cm}\end{array}$ & $6470 \pm 40$ & [6 894-7 023] & Globigerina bulloides & LLNL-73270 \\
\hline & $217-219$ & $8850 \pm 40$ & [9 469-9 532] & Globigerina bulloides & LLNL-73271 \\
\hline & $\mathrm{cm}$ & & & & \\
\hline & $261-265$ & $7290 \pm 50$ & [7 688-7 808] & Globigerina inflata & Poz-14638 \\
\hline & $\mathrm{cm}$ & & & & \\
\hline \multirow[t]{3}{*}{ MD01-2437 } & $316-318$ & $9240 \pm 50$ & [9 966-9 974]; [10 000-10 162] & Globigerina inflata & Poz-14643 \\
\hline & $453-456$ & $15350 \pm 80$ & [18 054-18 240]: [18 300-18 486] & Globigerina bulloides & Poz-14644 \\
\hline & $\mathrm{cm}$ & & & & \\
\hline \multirow[t]{3}{*}{ MD01-2438 } & $10-12 \mathrm{~cm}$ & $2340 \pm 30$ & [1 903-[1 998] & Globigerina inflata & Poz-14647 \\
\hline & $77-80 \mathrm{~cm}$ & $17310 \pm 90$ & [19 921-20 133] & Globigerina bulloides & Poz-14648 \\
\hline & $96-100 \mathrm{~cm}$ & $17260 \pm 80$ & [19 892-20 078] & Globigerina bulloides & Poz-14649 \\
\hline \multirow[t]{4}{*}{ KGMO-10 } & $44-46 \mathrm{~cm}$ & $11050 \pm 60$ & [12 666-12 799] & Globigerina bulloides & Poz-14621 \\
\hline & $89-91 \mathrm{~cm}$ & $14450 \pm 70$ & [16 540-16-954] & Globigerina bulloides & Poz-13813 \\
\hline & $118-121$ & $14940 \pm 70$ & [17 313-17 776] & Globigerina bulloides & Poz-14622 \\
\hline & $\mathrm{cm}$ & & & & \\
\hline MD01-2435 & $22-24 \mathrm{~cm}$ & $12940 \pm 70$ & [14 485-14 919] & Globigerina bulloides & Poz-14639 \\
\hline KSGC-12 & $22-25 \mathrm{~cm}$ & $15150 \pm 70$ & {$\left[\begin{array}{llll}17 & 746-18 & 030\end{array}\right]$} & Globigerina bulloides & Poz-14631 \\
\hline \multirow[t]{2}{*}{ KSGC-14 } & $51-54 \mathrm{~cm}$ & $14420 \pm 70$ & [16 501-16 916] & Globigerina bulloides & Poz-14625 \\
\hline & $69-71 \mathrm{~cm}$ & $15230 \pm 80$ & [17 843-18 159] & Globigerina bulloides & Poz-14627 \\
\hline
\end{tabular}

Table 1: Radiocarbon dating on the silt-sand layers in the deep basin of the Gulf of Lions. LLNL: Lawrence Livermore National Laboratory (USA), Poz: Poznan Radiocarbon Laboratory (Poland). 


\begin{tabular}{|c|c|c|}
\multicolumn{4}{|c}{ Percent biogenic material } \\
\hline 0 & (foraminifera, & 60 \\
\hline $\begin{array}{c}\text { silty-clay, or silt or } \\
\text { sand }\end{array}$ & $\begin{array}{c}\text { (foraminifera, calcareous } \\
\text { nannoplankton, } \\
\text { nannoplancton) } \\
\text { silty-clay }\end{array}$ & $\begin{array}{c}100 \\
\text { ooze }\end{array}$ \\
\hline
\end{tabular}

Table 2: Classification of sediment, after ODP Leg 155 Shipboard-Scientific-Party (1995), is based on the relative proportions of biogenic and lithic fractions

\begin{tabular}{|c|c|c|c|c|c|}
\hline $\begin{array}{l}\text { Bed } \\
\#\end{array}$ & $\begin{array}{l}\text { Amount } \\
\text { samples }\end{array}$ & $\begin{array}{l}\text { of Conventional radiocarbon age } \\
\text { (a BP) }\end{array}$ & $\begin{array}{l}\text { Calendar ages } \\
\text { (a BP) }\end{array}$ & $\begin{array}{l}\text { Average calendar } \\
\text { age (a BP) }\end{array}$ & Heavy mineral assemblage \\
\hline 1 & 5 & $840 \pm 30 ; 995 \pm 30 ; 1670 \pm 30$ & $\begin{array}{l}{[452-499] ;[548-615] ; \quad\left[\begin{array}{ll}1 & 202-1 \\
271\end{array}\right.}\end{array}$ & 900 & Languedoc \\
\hline 2 & 1 & $3540 \pm 35$ & [3 372-3 464] & 3400 & Languedoc \\
\hline 3 & 2 & $4370 \pm 35 ; 4705 \pm 35$ & [4 440-4 556]; [4 859-4 969] & 4700 & Languedoc \\
\hline 4 & 7 & $\begin{array}{l}6675 \pm 35 ; 6860 \pm 50 \\
6960 \pm 40 ; 7060 \pm 40\end{array}$ & $\begin{array}{l}{\left[\begin{array}{lll}7 & 167-7 & 244\end{array}\right] ;\left[\begin{array}{lll}7 & 323-7 & 421\end{array}\right] ;} \\
{\left[\begin{array}{lll}7 & 421-7 & 497\end{array}\right] ;\left[\begin{array}{lll}7 & 500-7 & 580\end{array}\right]}\end{array}$ & 7500 & Languedoc \\
\hline 5 & 1 & $7290 \pm 50$ & [7 688-7 808] & 7700 & Languedoc \\
\hline 6 & 2 & $9240 \pm 50 ; 9750 \pm 50$ & [10 000-10 062]; [10 547-10 654] & 10300 & Languedoc \\
\hline 7 & 2 & $11050 \pm 50$ & [12 679-12 791] & 12700 & Languedoc \\
\hline 8 & 1 & $13595 \pm 35$ & [15 440-15 770] & 15600 & Alps \\
\hline 9 & 1 & $14080 \pm 60$ & {$\left[\begin{array}{llll}16 & 075-16 & 470\end{array}\right]$} & 16000 & Alps \\
\hline 10 & 3 & $\begin{array}{l}14390 \pm 70 ; 14 \quad 420 \pm 70 ; 14 \\
450 \pm 70\end{array}$ & 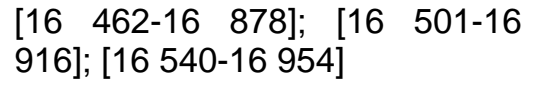 & 16700 & Languedoc \\
\hline 11 & 1 & $15010 \pm 40$ & [17 516-17 879] & 7. 17700 & 8. Not investigated \\
\hline 12 & 1 & $15510 \pm 50$ & [18 224-18 308]; [18 484-18 654] & 18400 & Languedoc \\
\hline
\end{tabular}

Table 3: Synthesis and characteristics of the 12 coarse beds identified in the study area: radiocarbon ages, calibrated (calendar) ages and heavy mineral assemblages 


\section{Figures}

Figure 1: Localisation and morpho-bathymetric map of the study area. LFC, La Fonera Canyon; CCC, Cap de Creus Canyon; LDC, Lacaze-Duthiers Canyon; PC, Pruvot Canyon; BC, Bourcart Canyon; HC, Hérault Canyon; SC, Sète Canyon; MC, Marti Canyon; PRC, Petit-Rhône Canyon; GRC, Grand-Rhône Canyon; EC, Estaque Canyon; MsC, Marseille Canyon; Plc, Planier Canyon; CaC, Cassidaigne Canyon. Numbering of sub-canyon is after Baztan et al. (2005). Distribution of sand on the shelf (very light grey) is after Aloïsi (1986) and Got and Aloïsi (1990). Position of the Petit-Rhône turbiditic system, PyreneoLanguedocian Ridge (light grey) and Petit-Rhône neofan (grey) is after Droz et al. (2006). Localisation of Figures 2, 3 and 7 is indicated. Open circles indicate sediment cores.

Figure 2: Interpretation of EM12 acoustic backscatter, redrawn from Droz et al. (2001). Open circles indicate position of sediment cores. Heterogeneous low backscatter zone was named the "Sète lobe", the lineated moderate backscatter zone was named the "La Fonera lobe".

Figure 3: EM300 shaded bathymetry (A) and acoustic backscatter (B) of the study area near the Petit-Rhône neochannel, scour field and abandoned channel (inlet). Dark tones correspond to high backscatter, light tones correspond to low backscatter. White lines indicate the position of bathymetric cross section from Figs. 9 and 10. Thick vertical line indicates position of MAK1 side scan sonar data shown in Fig. 11. Crosses indicate the position of in situ geotechnical measurements ("Module Géotechnique") shown in Fig. 8. Open circles indicate the position of sediment cores shown in Figs. 4, 9 and 10. The radiocarbon and calendar ages (in italics) are those of the base of the hemipelagic drape. Note the roughness of the seabed and the patchy pattern of the acoustic backscatter.

Figure 4: Lithologic logs of sediment cores. Silt-sand layers are indicated with a dotted pattern. Arrows indicate conventional radiocarbon dates. Numbers in circles indicate the coarse bed number. Positions of sediment cores are shown in Figs. 1, 2 and 3. a) Sediment cores at the outlet of the Sète canyon network and at Petit-Rhône neofan. Correlation line indicates the limit between the Western Discordant Body sensu Droz and Bellaiche (1985) (i.e. the Petit-Rhône neofan deposits or the Western Mass Transport deposits) and the hemipelagic drape with intercalated coarse layers. b) Sediment cores on the Petit-Rhône turbiditic system, upstream the channel avulsion and on the abandoned channel. Correlation line indicates the limit between the Petit-Rhône leveed turbiditic deposits, and the hemipelagic drape. Several sediment cores are much longer than shown in the figure.

Figure 5: Photos (a), processed X-ray images (b) and median grain size (c) of coarse layers from bed \#1 (left) and from bed \#4 (right). Positions on sediment cores are shown on Figs. 1, 2 and 3. Note the different scale bar for layer KSGC-10 2-5 cm. Note the very variable thickness of the layers as well as the strongly erosional base of layer KIGC-06 24-32 cm. Note the normal grading and constant grain size of the bottom of the layer and the thin finer top.

Figure 6: Statistical distribution of the median grain size for all grain size analyses carried out on the coarse layers. Note the abundance of class 100-200 $\mu \mathrm{m}$ corresponding to the main body of several layers as seen in Fig. 5 . Note the bimodal distribution in the finest medians that are silty $(40-50 \mu \mathrm{m})$ and sandy $(70-80 \mu \mathrm{m})$. The coarsest medians $(900-1000 \mu \mathrm{m})$ correspond to layer MD01-2438 54-75 cm.

Figure 7: Maps showing the distribution, age and heavy mineral signature of the silt-sand beds (red circles), hemipelagic sediment (yellow circles), sedimentary hiatuses, dated (dark blue circles) and interpreted (light blue circles). At the bottom-left, the yellow and red circle 
indicate sediment core MD01-2438 (not on the map) that contains a sandy layer of undetermined age. The circle with a cross indicates that the sediment core did not sample the given period of time. Arrows indicate the provenance of silt-sand material, red arrows indicate dominantly depositional (silt-sand beds) currents, blue arrows indicate dominantly erosive currents.

Figure 8: In situ geotechnical data. Qc (fine black curve) represents the tip resistance. $\Delta \mathrm{u}_{2}$ (thick black curve) is the differential pore pressure. Squares indicate the soil classification after Ramsey (2002). 1: extra sensitive clay; 2: organic clay and peat; 3 and 4: clay; 5: clayey sand; 6: sandy very clayey silt; 7: sandy silt to sand; 8: silty sand; 9: clean sand. This classification does not refer to the real composition of the sediment but to a mechanical behaviour equivalent of soils. Grey squares indicate classification $<7$, black squares indicate classification $\geq 7$. Position is shown in Fig. 3. Grey strips indicate probable coarse layers and correspond to a (1) concomitant increase in Qc and decrease in $\Delta \mathrm{u}_{2}$, (2) Ramsey classification $\geq 7$. Grey pattern indicates the hemipelagic drape. Dotted pattern indicates data with high frequency and low amplitude variation.

Figure 9: Bathymetric cross-section along MGGC-03 transect of in situ geotechnical measurements (see position in Fig. 3). Vertical exaggeration is about 80. Interpretation of geotechnical data in terms of silt-sand layers, as shown in Fig. 8, is reported at the same scale. Photos and lithological logs of sediment core have a different scale. Grey pattern indicates the hemipelagic drape with intercalated silt-sand layers. Radiocarbon and calendar (italic characters) ages are those of the base of the hemipelagic drape. Note that hemipelagic sediment is less abundant on steep slopes and in the lows. The key for the lithological logs is given on Figure 4.

Figure 10: Bathymetric cross-section along MGGC-04 transect of in situ geotechnical measurements (see position on Fig. 3). Vertical exaggeration is about 80. Interpretation of geotechnical data in terms of coarse layers as shown in Fig. 8 is reported at the same scale. Photos and lithological logs of sediment cores have different scales. A grey pattern indicates the hemipelagic drape with intercalated coarse layers. Radiocarbon and calendar (italics) age is that of the base of the hemipelagic drape. Note that hemipelagic sediment is less abundant along high slopes and in the lows. The key for the lithological logs is given on Figure 4.

Figure 11: MAK1 $30 \mathrm{kHz}$ side scan sonar image (a), $5.5 \mathrm{kHz}$ sediment penetrator (b) and interpretation (c) across giant scours, adapted from Kenyon (1995). Dark tones correspond to high backscatter, light tones correspond to low backscatter. Note position of the cores and projection on the profile. Position of profile and sediment cores is shown in Fig. 3. NTU: Neofan Transparent Unit; NCU; Neofan Chaotic Unit; WMTD: Western Mass Transport Deposit. Note that there is almost no hemipelagic drape inside the scour while aside, it is 50 $\mathrm{cm}$ thick with a $10 \mathrm{~cm}$ thick coarse layer. The eroded bottom of the scour is a window on the deeper WMTD as seen on core KSGC-10.

Figure 12: Principal Components Analysis (PCA) and correlation circles for the three main components (axis) on heavy mineral assemblages from the coarse layers. Only minerals with correlation coefficient higher than the maximum curvature of the curve fit were considered as significant. Composition of axes and interpretation in terms of source is given in Fig. 13. Six classes interpreted in terms of sediment source are determined on the correlation circles.

Figure 13: Ascending Hierarchical Classification (AHC) obtained on the coarse layers for the six classes determined by the Principal Components Analysis. Note the characteristic heavy mineral assemblage of the classes and their interpretation in terms of sediment source. The asterisk $\left({ }^{*}\right)$ corresponds to a sample possibly sucked up from deeper layers during coring. 
Figure 14: Relative sea-level curves for the deglaciation and the Holocene, position of coarse beds and main sedimentary and hydrodynamical processes on the deep basin and on the outer shelf. Thick curve and grey triangles are sea-level from Camoin et al. (2004), thin large dash line is sea-level from Hanebuth et al. (2000), thin small dash line is sea-level from Fairbanks (1989). The age of the coarse beds is projected on the sea-level curves (open circles). The minimum and maximum age for a coarse layer is represented by the grey pattern. Shelf processes and deposits are after Bassetti et al. (2006). Outer shelf wave cut terraces are after Jouet et al. (2006). Depth of the canyon heads was determined after the bathymetric map of Berné et al. (2001) and corrected for $-15 \mathrm{~m}$ corresponding to the tectonic subsidence and the post-glacial hydrostatic subsidence reference. Time interval before flooding of the canyon head in dark grey pattern is based on sea-level curves from Fairbanks (1989), Hanebuth et al. (2000) and Camoin et al. (2004). 

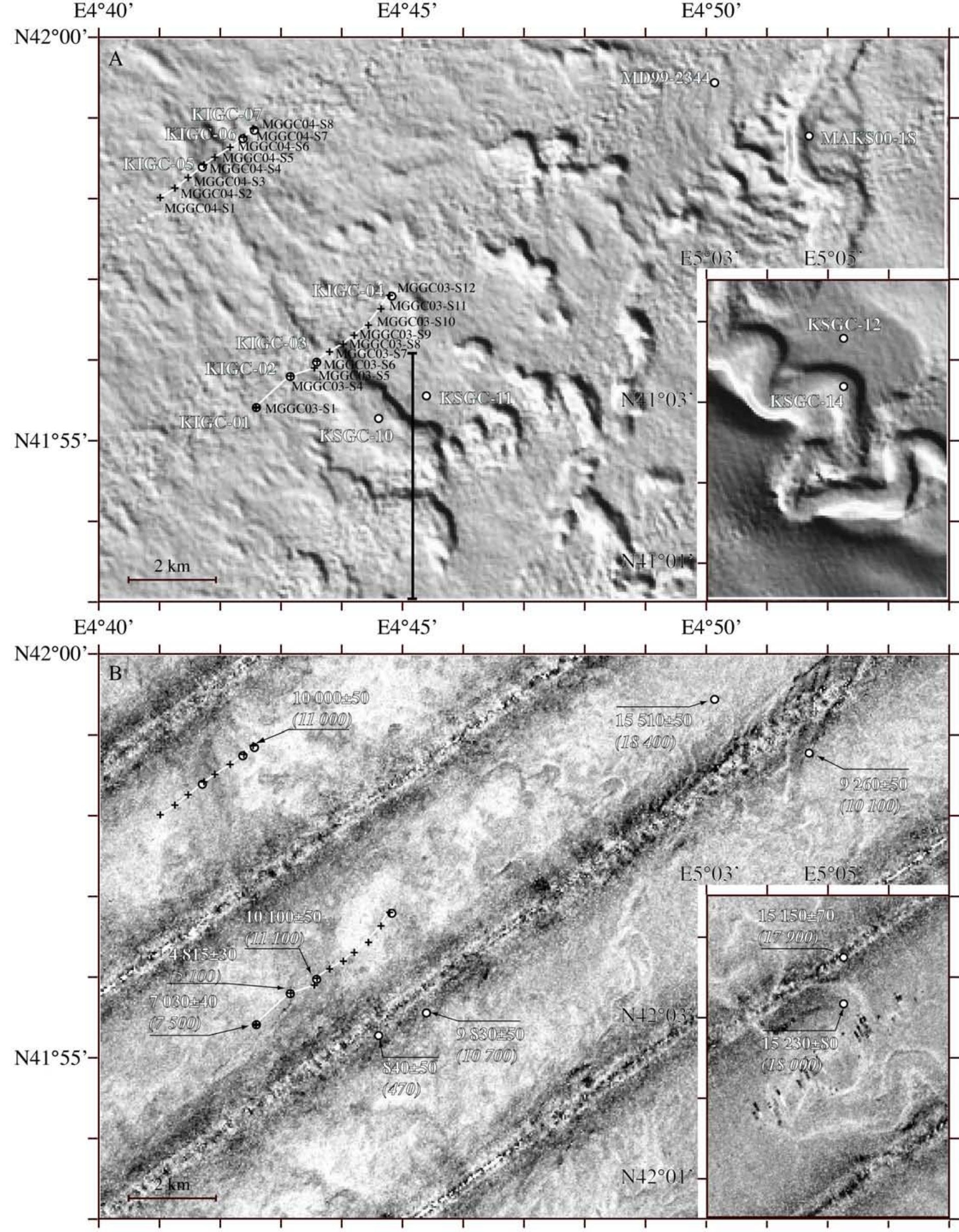

Figure 3 - Dennielou et al., Sand beds GoL 
a) MD99-2344

\section{KIGC-01}

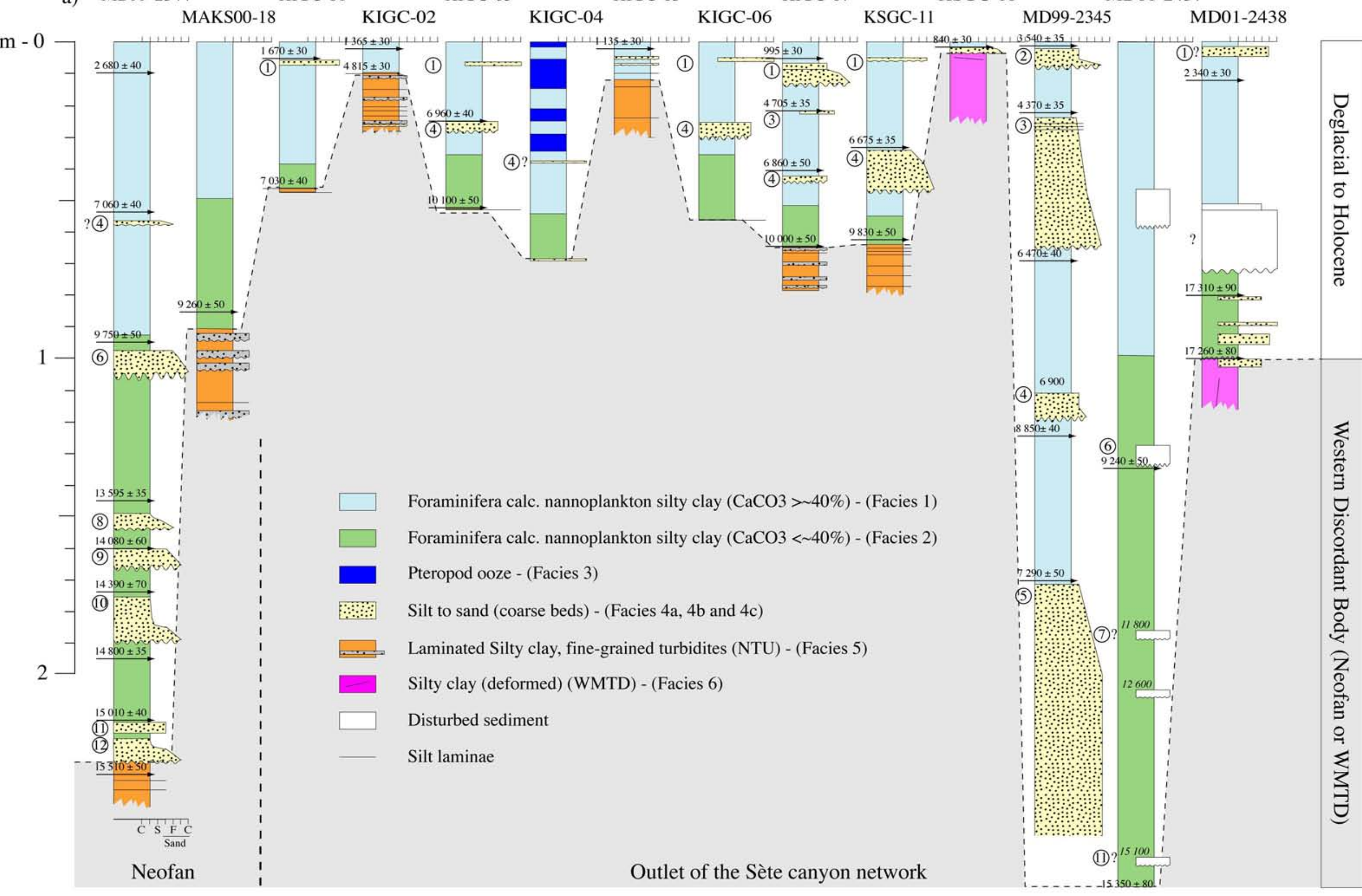

Figure 4 - Dennielou et al., Sand beds GoL 
b) KGMO-10

KSGC- 12

m - 0

MD01-2435

KSGC-14

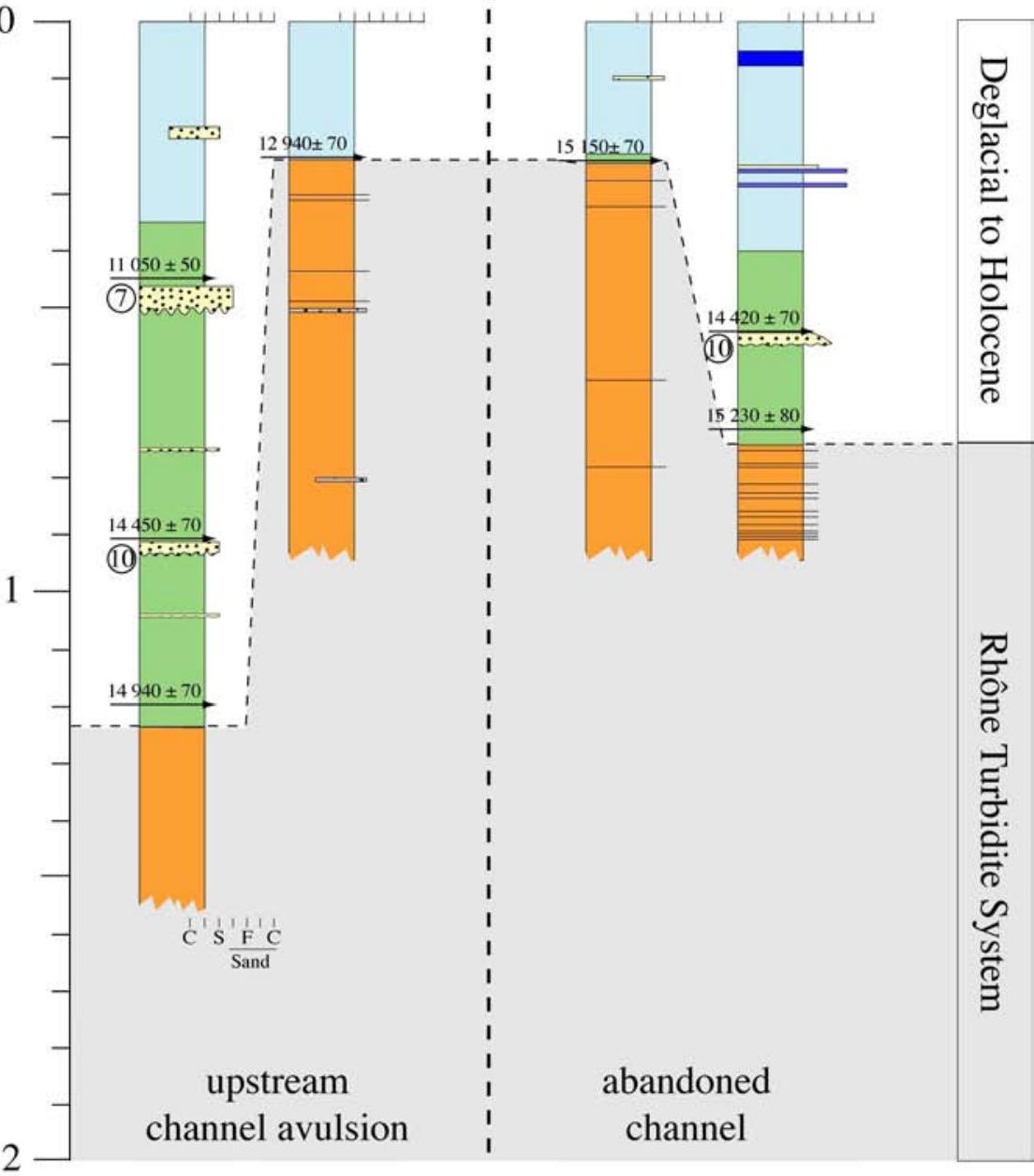

Figure 4 (end) - Dennielou et al., Sand beds GoL 


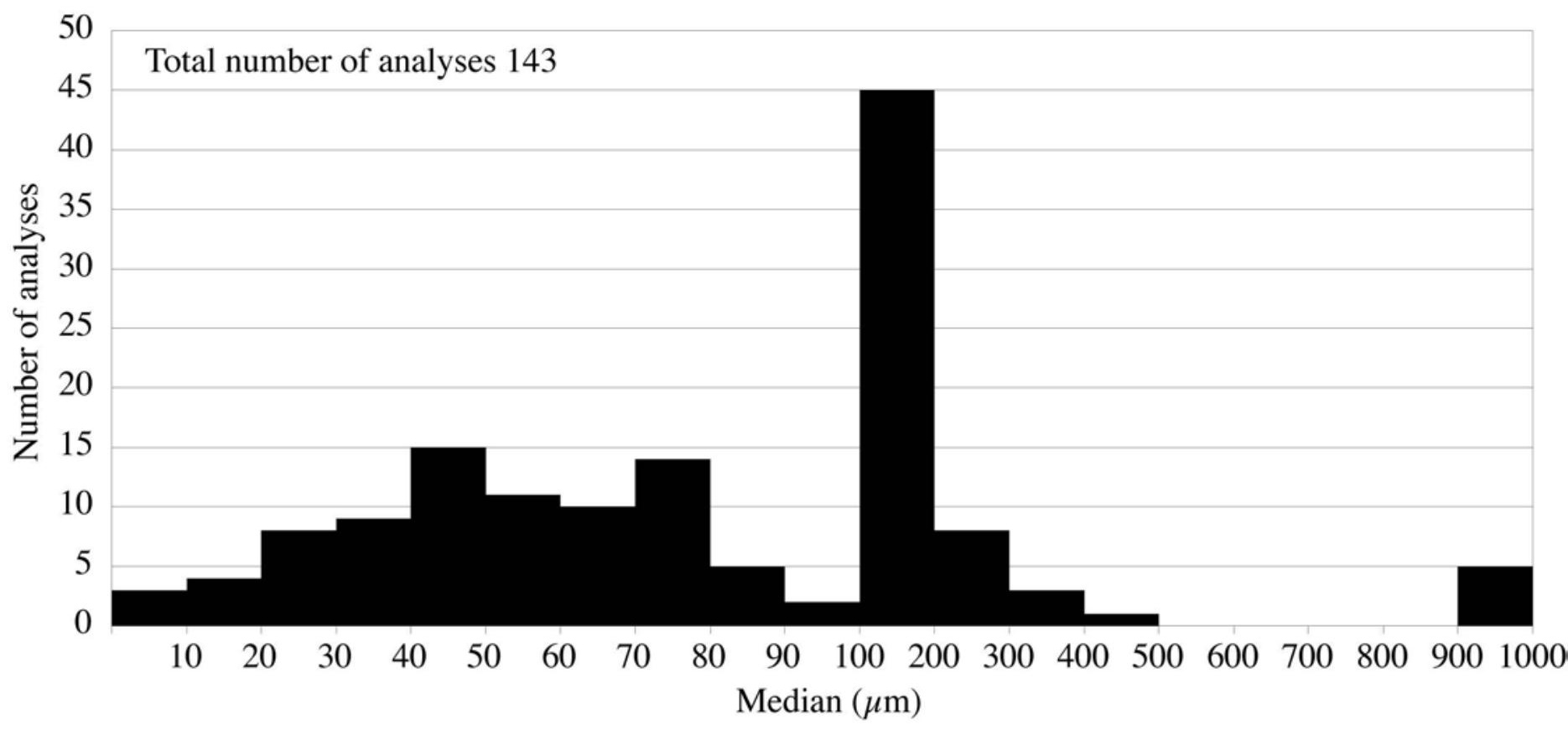

Figure 6 - Dennielou et al., Sand beds GoL 


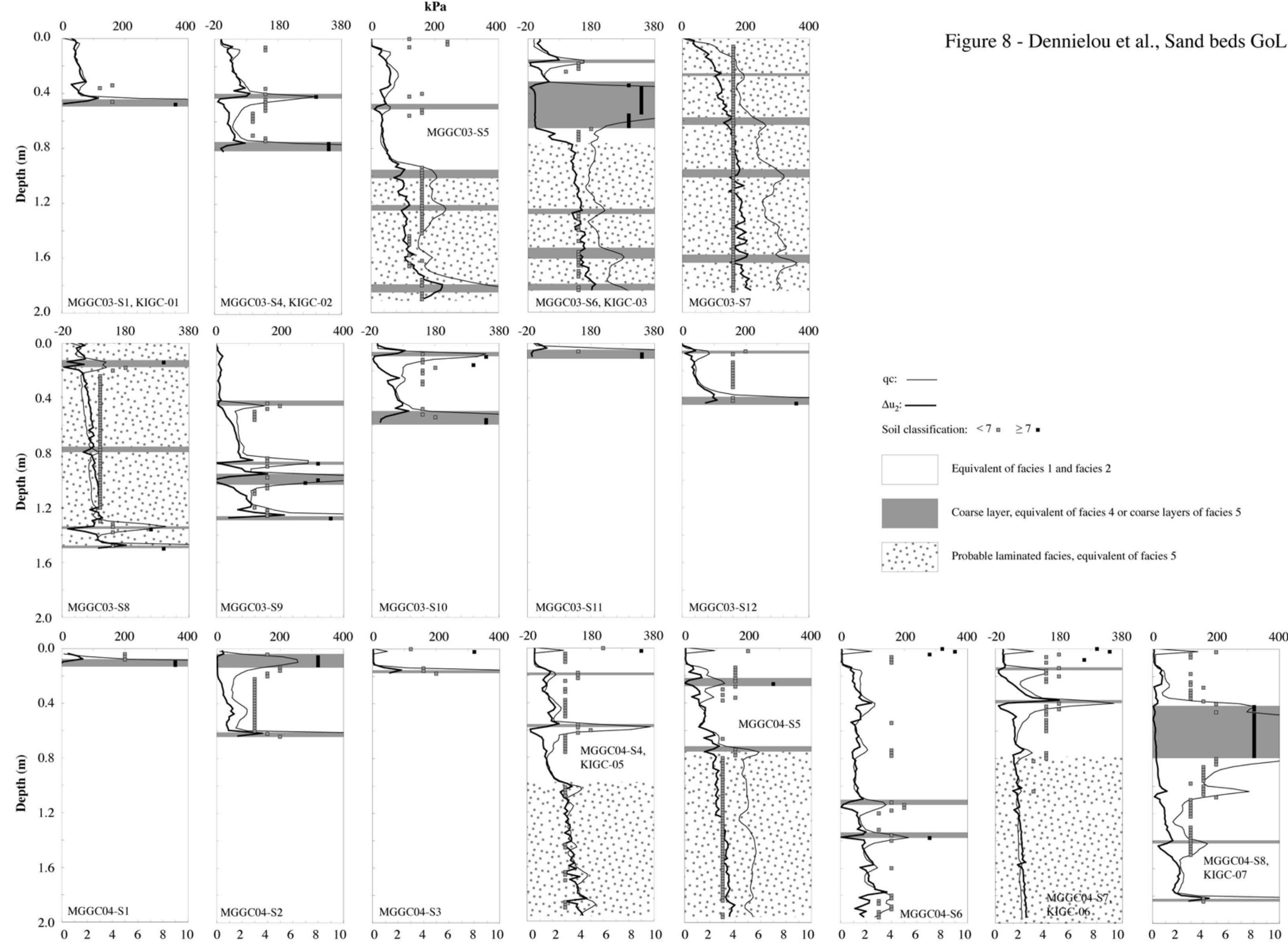




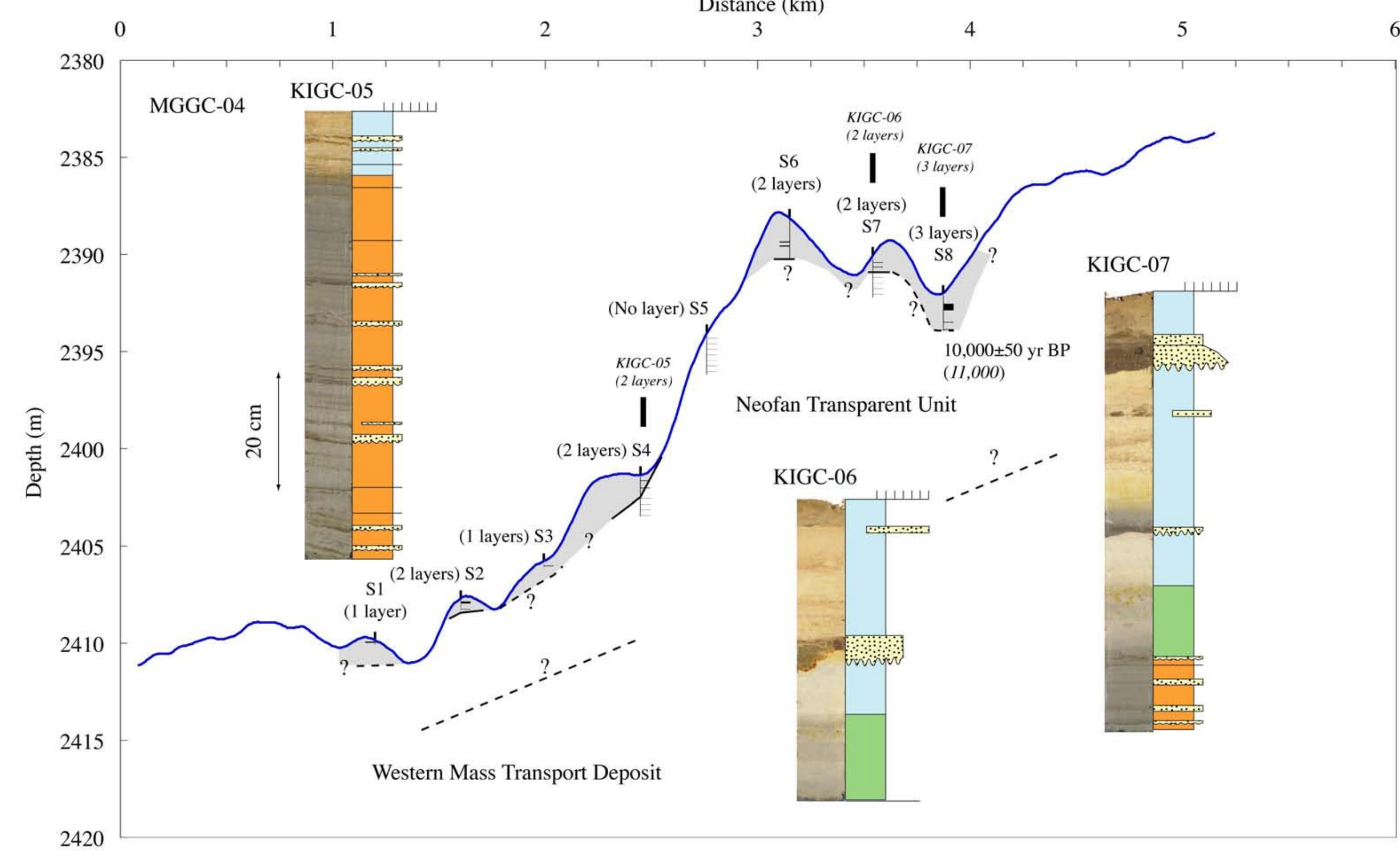

Figure 10 - Dennielou et al., Sand beds GoL 


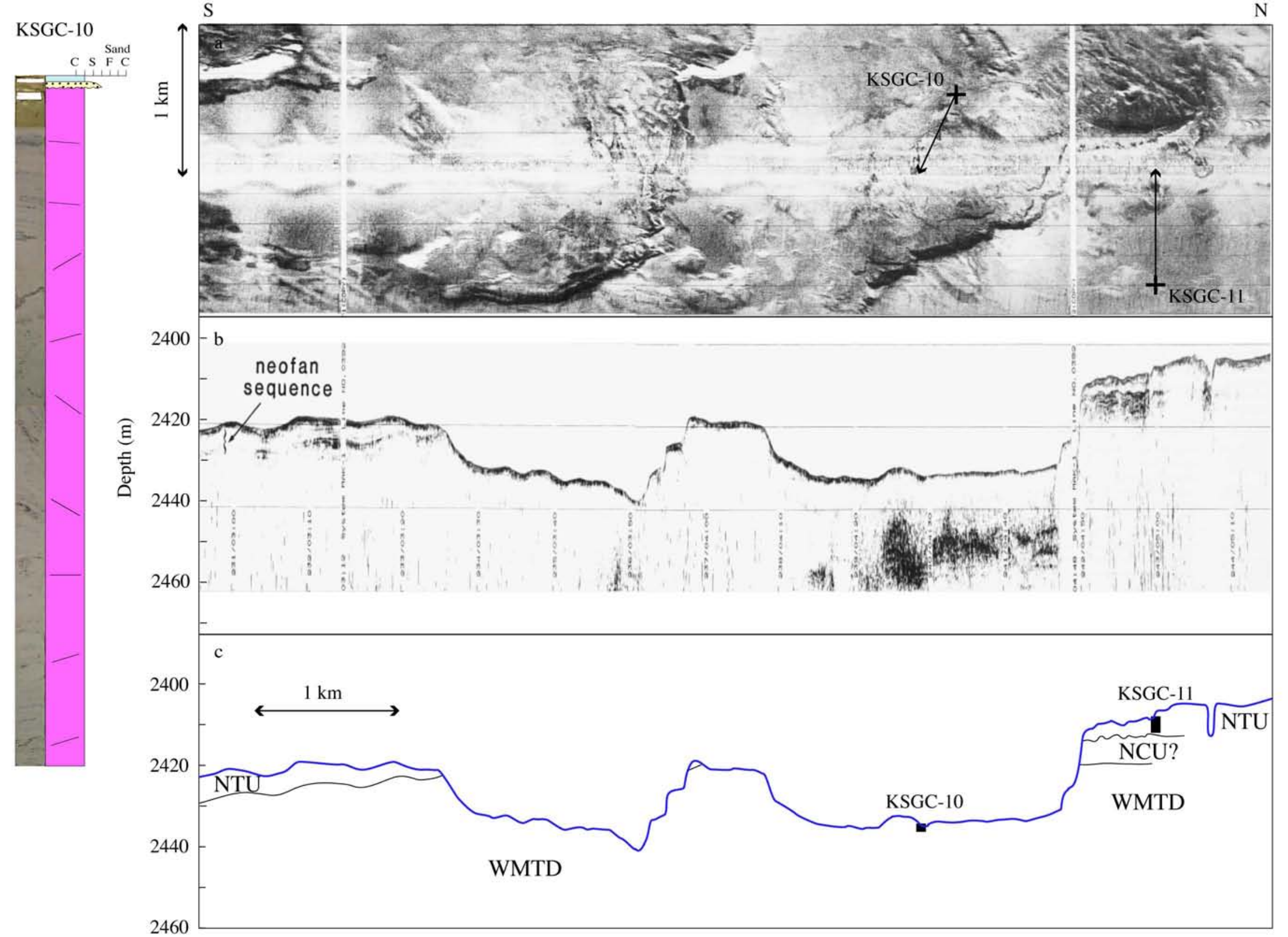

an

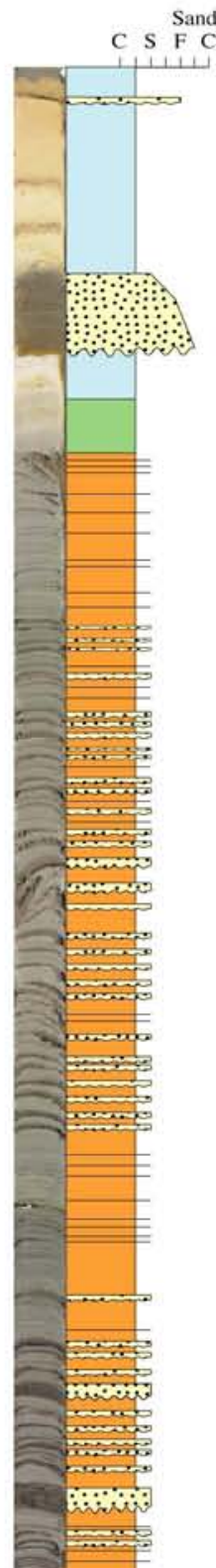

Figure 11 - Dennielou et al., Sand beds GoL 

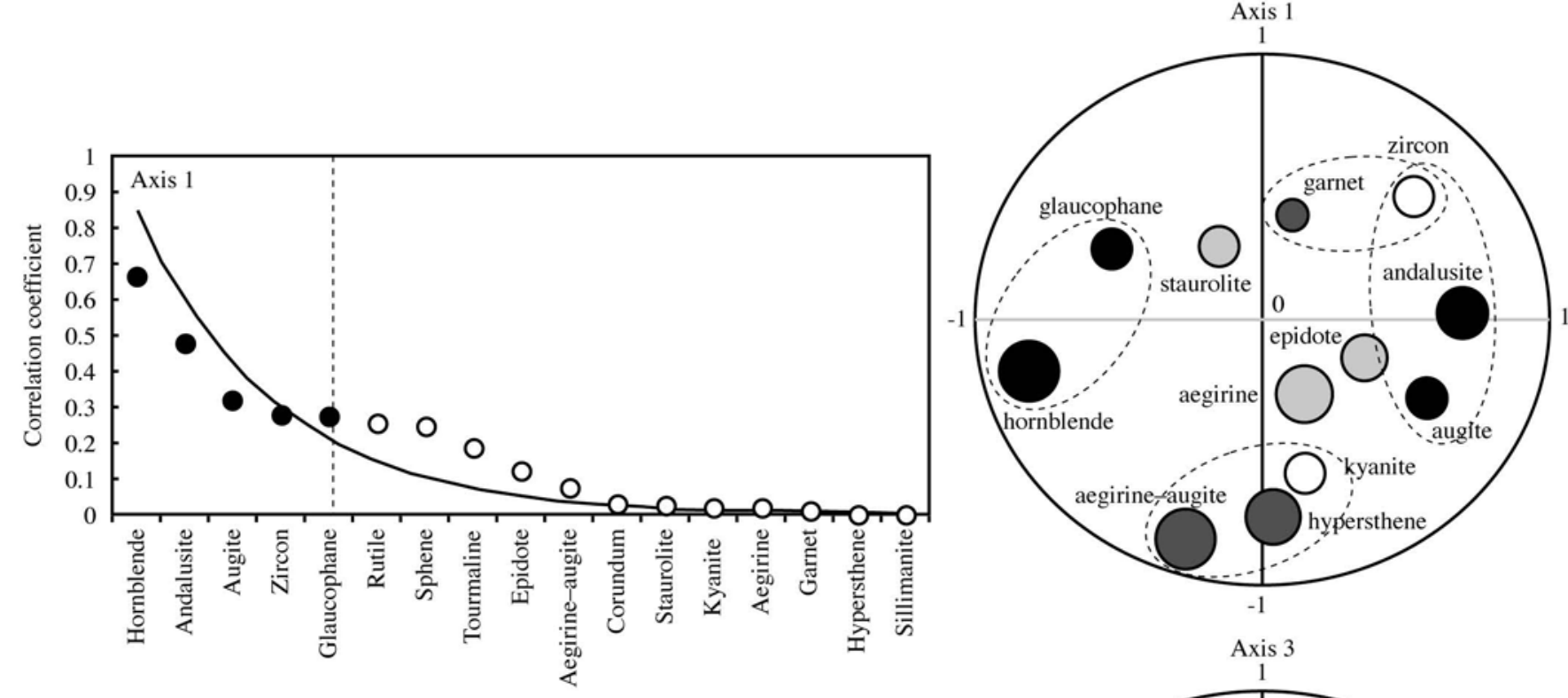

1 Axis 2
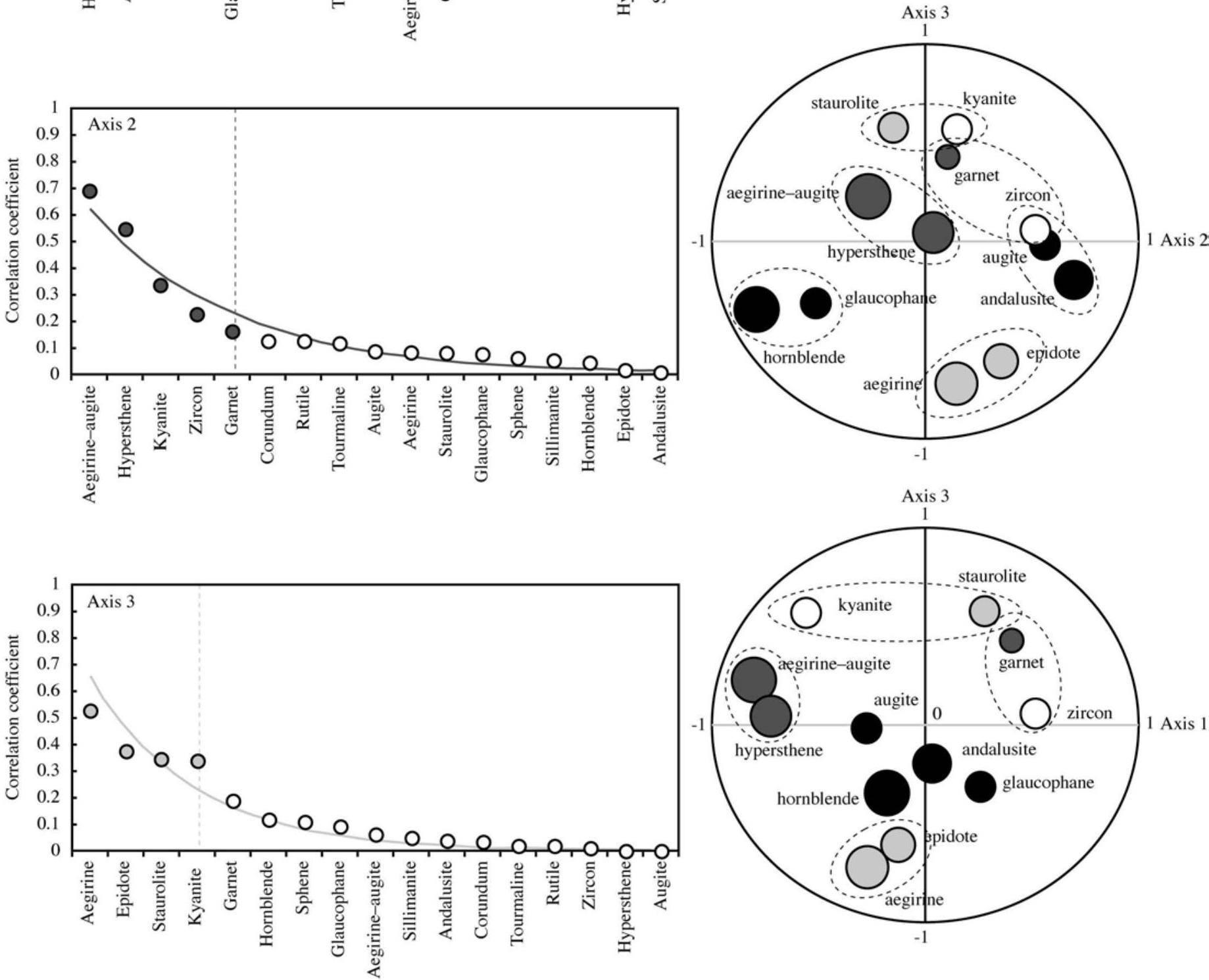

Figure 12 - Dennielou et al., Sand beds GoL 


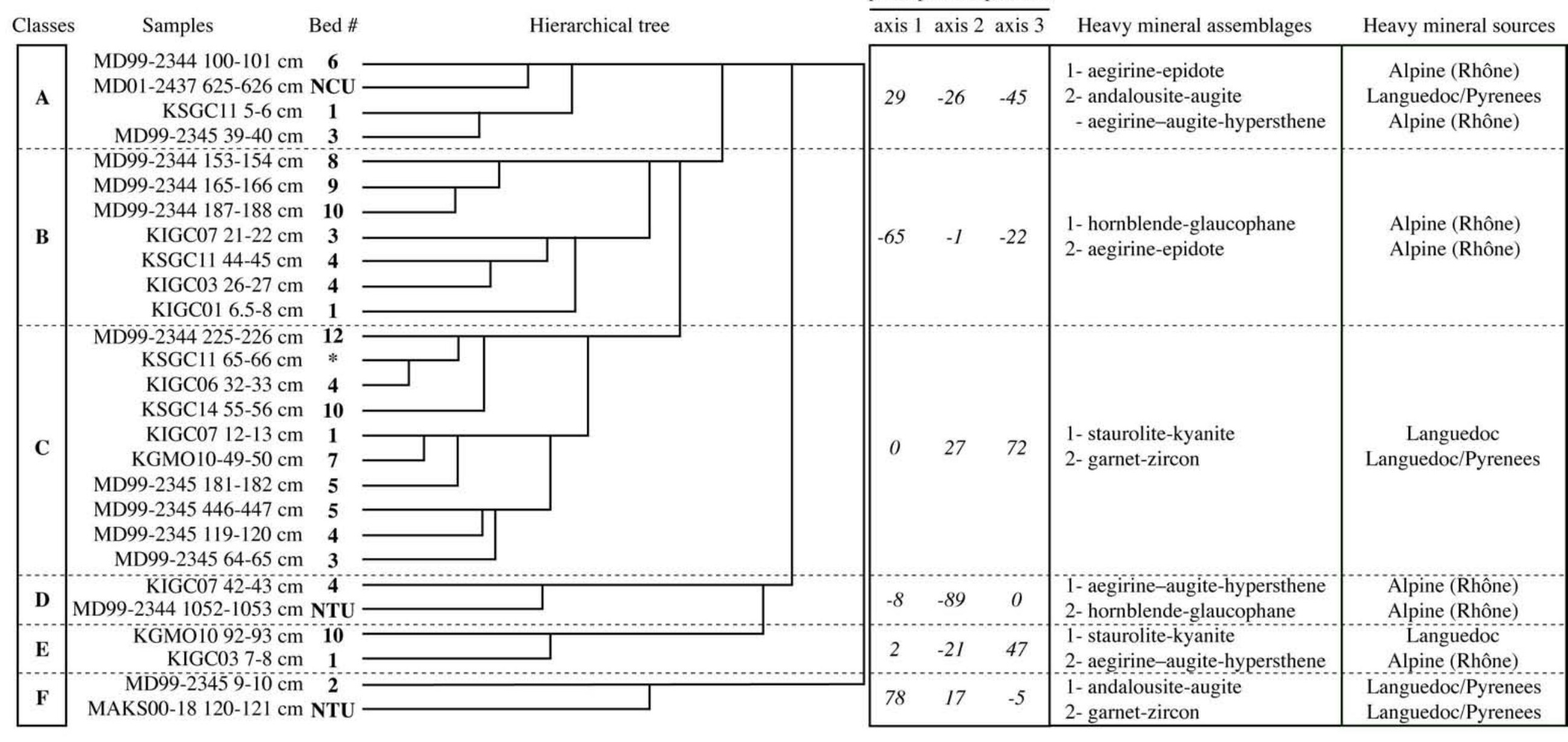




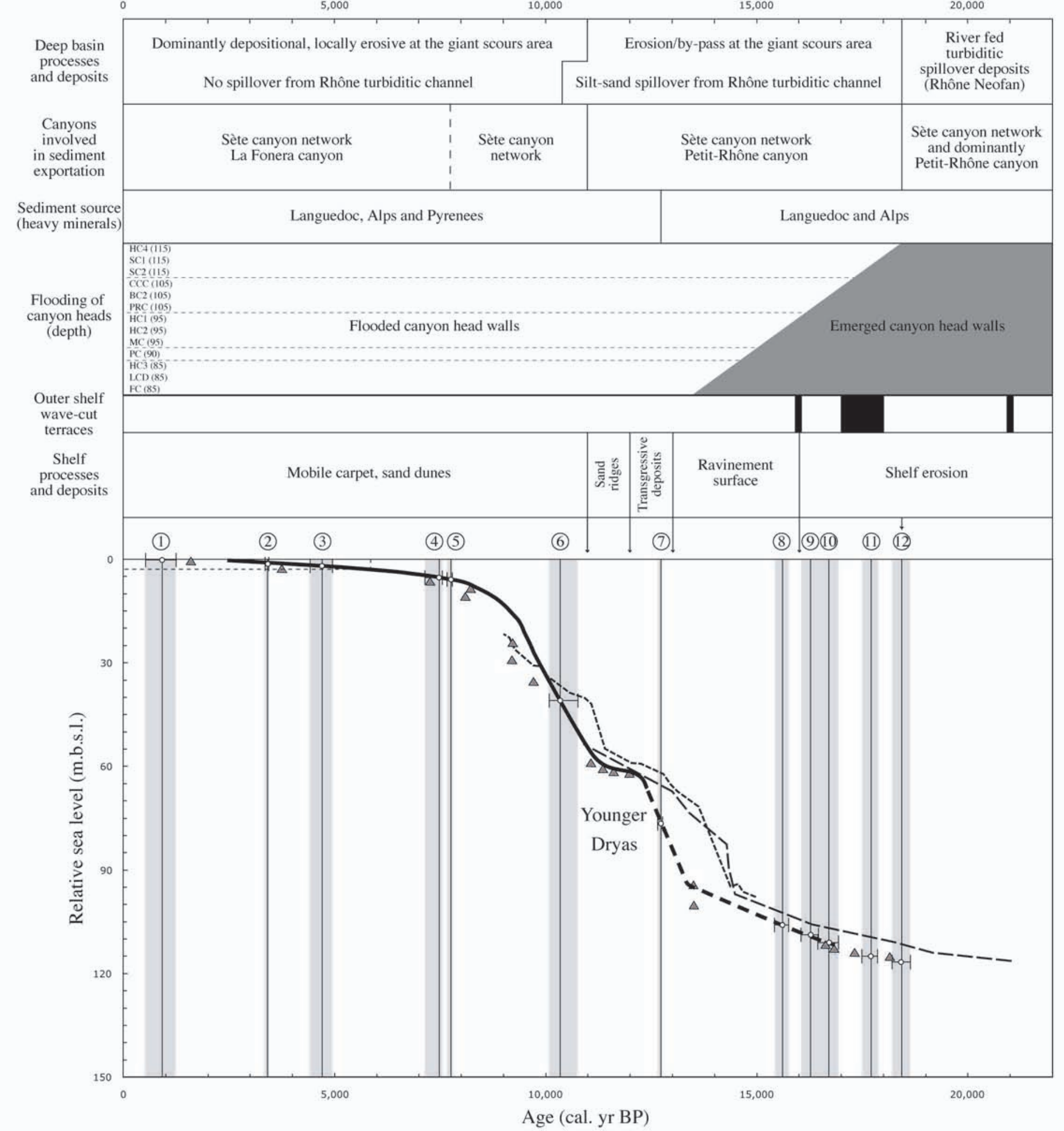

Age (cal. yr BP)

Figure 14 - Dennielou et al., Sand beds GoL 